2019

\title{
An Alternative Path to Rule of Law: Thailand's Twenty-First Century Administrative Courts
}

Frank W. Munger

Peerawich Thoviriyavej

Vorapitchaya Rabiablok

Follow this and additional works at: https://digitalcommons.nyls.edu/fac_articles_chapters

Part of the Comparative and Foreign Law Commons 


\title{
An Alternative Path to Rule of Law?
}

\section{Thailand's Twenty-First Century Administrative Courts}

\author{
Frank W. Munger, PEerawich ThOVIRIYAVEJ, VORAPITCHAYA \\ RABIABLOK \\ INTRODUCTION-NEW COURTS IN ASIA
}

\begin{abstract}
New courts in Asia's rapidly developing states offer an opportunity to understand how a court system takes root in a society. This article presents a case study of the development of administrative court structure, functions, and practice in Thailand: Southeast Asia's newest system of administrative courts. Thailand's new courts are not an isolated example. Throughout the nineteenth and twentieth centuries in Asia and elsewhere, colonial rulers and traditional elites adapted European or American judicial institutions and practices as a means to centralize and secure their power. ${ }^{1}$ Late twentieth century pressures experienced by many developing states to expand the flexibility of private markets and empower civil society have demanded further adaptations of state structure and authority. ${ }^{2}$ In response to these pressures, judicialization-the expansion of judicial authority at the expense of other institutions of governance-has become a nearly universal feature of transitions from traditional to modern states in the
\end{abstract}

1. See, e.g., Daniel S. Lev, Legal Evolution and POLItical Authority in INDONESIA: SELECTED EsSAYS (2000); JUdICIAL INDEPENDENCE IN CHINA: Lessons FOR Global Rule of LaW Promotion (Randall Peerenboom ed., 2009); Frank W. Munger, Law and the Legal Profession in Thailand, in LAWYERS IN SOCIETY (Richard L. Abel, et. al. eds., forthcoming 2018).

2. See Andrew Harding \& Penelope Nicholson, New Courts in Asia: Law, Development, and Judicialization, NEW COURTS IN ASIA 1, 2-4 (Andrew Harding \& Penelope Nicholson eds., 2010).

Indiana Journal of Global Legal Studies Vol. 26 \#1 (Winter 2019)

(C) Indiana University Maurer School of Law 
developing world. ${ }^{3}$

Theories of the establishment of courts in developing countries under pressure to modernize governance argue that courts appeal to traditional elites with declining power as a means to control political change. ${ }^{4}$ A great deal of evidence supports the argument that the purposes of elites who support new courts are self-serving, ${ }^{5}$ but wide variation in the history and performance of particular courts suggests the theory's limitations. ${ }^{6}$ Moreover, while scholars have written primarily about constitutional courts, administrative courts play a different, and potentially far larger, role by overseeing the day-to-day relationships between a government and its citizens in ways other courts lack the power to do. ${ }^{7}$

Thai administrative courts provide an opportunity to examine the development of new courts in an unstable political environment, which is a characteristic of many developing societies. Thailand's Constitutional Court and administrative court system were created in 1997 by a celebrated liberal constitution that established full democracy and independent institutions to oversee the new constitutional order. After almost ten years of increasing conflict over corruption by overreaching populist Prime Minister Thaksin Shinawatra, the system of democratic checks and balances was in collapse. In 2005, the Constitutional Court invalidated an election called by Thaksin but boycotted by the opposing party. A military coup set the constitution aside and drove Thaksin from office in 2006. After a little more than a year, neither adoption of a revised constitution nor restoration of elected government under a revised constitution in 2007 mitigated deep political divisions, street violence, or political instability. A second military coup, in 2014, has placed elected government on hold once again. After these events, the Constitutional Court has been widely perceived as politically tainted, first by Thaksin's influence and after constitutional revision under military supervision in 2007, by his

3. See The Global Expansion of Judiclal Power (C. Neal Tate \& Torbjorn Vallinder eds., 1995).

4. See Ran Hirschl, Towards Juristocracy: THE Origins and Consequences of THE NEW CONSTITUTIONALISM 31-49 (2004).

5. See id. at 38-49.

6. See Tom Ginsburg, The Judicialization of Administrative Governance: Causes, Consequences and Limits, in ADMINISTRATIVE LAW AND GOVERNANCE IN ASIA: Comparative Perspective (Tom Ginsburg \& Albert H.Y. Chen eds., 2009). See also the comparative studies in Yves Dezalay \& BRyant G. Garth, Asian Legal Revivals: LAWYERS IN THE SHADOW OF EMPIRE (2010).

7. See Ginsberg, supra, note 6 , at 1 . 
opponents who are allied with the military. ${ }^{8}$ In contrast to the Constitutional Court's controversial role during this political turmoil, the administrative courts have emerged from the political conflict with a relatively unblemished image based on a well-publicized track record of successful confrontations with high ranking officials and powerful agencies. ${ }^{9}$

In practice, courts, like the rule of law itself, derive their function from the political purposes they serve. ${ }^{10}$ Legal ideals and practices in Western democracies have great appeal both for power holders seeking to legitimize their authority and the relatively powerless who want to hold the powerful accountable and seek wider opportunities for themselves. Nevertheless, as China scholar Rachel Stern observes, using formal similarities or ideological pronouncements alone as a measure of legal development diverts our attention from "quieter shifts more indicative of how law seeds itself in tough terrain." 11 Western legal institutions and practices take hold, political scientist Dan Lev observed after many years of studying legal systems in Southeast Asia, "only when they make sense domestically and are adapted to domestic purposes." 12

This study examines why courts made sense to those who established them and how the courts' authority is being utilized. For relatively powerless and resource-poor litigants, barriers to litigation may be many, but when these barriers are overcome, administrative courts exercise extraordinary influence, even when they fail to render a decision fully vindicating a plaintiff's legal rights. Administrative courts serve multiple functions, not only by exercising power, in the famed words of Chief Justice Marshall, "to say what the law is," 13 but also by decentering the concentrated power of Thailand's insular and tradition bound ministries as well as its politicians. Binding decisions can

8. See Björn Dressel, Judicialization of Politics or Politicization of the Judiciary? Considerations from Recent Events in Thailand, 23 PAC. REV. 671, 676-78 (2010); see also Eugénie Mérieau, Thailand's Deep State, Royal Power and the Constitutional Court (19972015), 46 J. OF CONTEMP. ASIA 445 (2016).

9. See generally the overview of the administrative courts' statutory structure, powers, and earliest landmark decisions in Peter Leyland, The Emergence of Administrative Justice in Thailand Under the 1997 Constitution, in ADMINISTRATIVE LAW AND Governance in Asia: Comparative Perspectives 230 (Tom Ginsburg \& Albert H.Y. Chen eds., 2008).

10. See Dietrich Rueschemeyer, Comparing Legal Professions: A State Centered Approach, in LaWyers in SOCIETY: COMPARATIVE THEORIES 289, 311-15 (Richard L. Abel \& Philip S. Lewis eds., 1988).

11. Rachel E. Stern, Environmental Litigation In China: A Study in Political AMBivalenCE 211 (2013).

12. Lev, supra note 1 , at 6 .

13. Marbury v. Madison, 5 U.S. 137, 177 (1803). 
exercise what Michael Dowdle calls concurrent jurisdiction to counter concentrated executive or political control over policy making through authority of their own that is directed to enforcing the rule of law. Courts' convening power requires officials to engage other stakeholders and to attend to the consequences of policy from other perspectives. Finally, courts possess expressive functionality by providing a forum in which citizens' interpretations of policy and new perspectives on state authority can sometimes be communicated to others when political space is limited. ${ }^{14}$ Each of these functions create an alternative center of power and opportunities for change. In practice, the impact of a court system depends on a web of actors that includes judges, bureaucrats, police, prosecutors, potential litigants, and supporting networks, and may extend far beyond to global sources, ideological influence, and material support.

Understanding how judges, litigants, and other actors have adapted to the administrative courts requires context. Our examination is both "top down" and "bottom up." 15 We emphasize the courts' institutional origins and development, and we consider how the courts' authority is perceived and deployed by judges, potential litigants, and their advocates. The factors influencing the mobilization of litigation and how courts draw officials and citizens together through a web of courtcentered relationships are then discussed. Parts II and III describe the history of the courts' origins to lay bare the political contingencies that determined the power given the courts as the Thai state underwent political transitions. Part II places the administrative courts in historical perspective, describing the development of courts in Thailand and their place in relation to the monarchy (the government's symbolic core) and the powerful bureaucratic state. Part III describes the constitutional and statutory powers given to the administrative courts. Part IV describes the administrative courts in action. We present a statistical overview of cases filed since the administrative courts opened in 2001 and an analysis of the courts' caseload. The caseload of the courts shows that litigation is concentrated in a few areas of government administration, and litigants typically have a continuing relationship with government regulators or are government officials themselves.

More surprising is the increasing frequency of environmental rights

14. See Michael W. Dowdle, On the Regulatory Dynamics of Judicialization: The Promise and Perils of Exploring "Judicialization" in East and Southeast Asia, in Administrative Law and Governance in Asia: Comparative Perspectives 23, 24-25, 30 (Tom Ginsburg \& Albert H.Y. Chen eds., 2008).

15. Our analysis benefits from Ginsburg's insightful introduction to one of the few collections of scholarship on Asian administrative courts. Ginsburg, supra note 6, at 1. 
litigation where litigants have little familiarity with government regulation and limited means or knowledge to litigate. In Part $V$, we undertake a case study of one type of litigation's development to illustrate the dependence of and effectiveness of litigation for rights on a system of "support structures." 16 Thailand lacks many of the supporting institutions and practices typical of developed Western democracies, such as a politically savvy and powerful legal profession, a rightsconscious judiciary, influential public and private organizations supporting litigation for rights, and public consciousness of rights. Yet following constitutional reform, rights-oriented litigation emerged in the administrative courts through the efforts of a small, self-sustaining community of activist attorneys. We describe the career of a leading environmental litigator and his network and the mutually constructive effects of the outcomes of this litigation on the support structures for the courts.

A concluding Part VI draws on the foregoing analysis to address a question posed by many Western observers of new judicial systems: Do new administrative courts provide an alternative path for the rule of law? We find that under both democratic and military rule, the administrative courts have provided a means of accountability accessible to ordinary Thai citizens. We identify factors that influenced this possibility and provide starting points for comparisons with the courts of other developing countries as well as with judicial systems in developed democratic states.

\section{'THAILAND's JUdiciaRY AND DEVELOPMENT OF ITS MODERN STATE}

\section{The Kadar Toy Factory Fire}

On the evening of May 10, 1993, fire swept through the shop floor of the Kadar Toy factory in [Bangkok]. Fed by piles of fabric scraps and aided by the absence of fire prevention systems, the fire took 188 lives and injured 449. The fire was not Kadar's first, and government officials shared blame for the disaster. Management malfeasance played a primary role, but woefully inadequate oversight by ministries contributed to the outcome. Responsibility might be extended further. Government hostility to labor unions followed from its pro-development policies. The International Labor Organization lectured about safe workplaces but did little to document or prevent failures on the ground.

16. Charles R. Epp, The Rights Revolution: Lawyers, ACtivists, and Supreme Courts in Comparative Perspective 2-6 (1998); see also Ginsburg, supra note 6, at 8-9. 
17

The expense and uncertainty of litigation for working poor meant that families settled for an average of $\$ 7,000 .{ }^{18}$ A Kadar-affiliated company donated money for the education of victims' children. The building engineer eventually lost his license. Four Kadar executives were fined \$12,280. One individual was criminally prosecuted - a worker accused of igniting the fire with a cigarette.

There was no remedy for the government's neglect-its ineffective oversight and failure to enforce workplace safety standards. Proposals for reform died in committees. The government's nominal oversight remained nominal.

\section{Adapting to European and American Imperialism}

Thailand's progressive monarchs preserved their autonomy from nineteenth century, European colonial powers by entering into commercial treaties, which grant extraterritorial legal rights to foreign businesses and merchants, and by initiating a plan to create a modern bureaucratic state with a highly centralized system of government administration and courts. A modern state structure served dual purposes-gaining the respect of (and independence from) foreign powers and centralizing authority over the monarchy's diverse domains. ${ }^{19}$ Rama V (1868-1910) created bureaucratic ministries in 1888, placing them under the control of members of the royal family and trusted advisors. Soon after, he developed a centralized system of civil courts (officially Royal Courts of Justice), a project overseen by his brother who was a lawyer trained in England. A legal code modeled on European civil law replaced a feudal code administered regionally in courts under the control of local nobility. ${ }^{20}$

Two factors contributed to the long afterlife of this structure, which centered on the legitimacy and power of the monarchy. First, Rama VI

17. See Fiona Haines, Globalization and Regulatory Character: Regulatory REFORM AFTER THE KADER TOY FACTORY FIRE (2005).

18. See Casey C. Grant, Case Study: The Kader Toy Factory Fire, EnCYCLOPEDIA OF OCCupational Health \& SAFETy (Feb. 26, 2011, 8:55 PM), http://www.iloencyclopaedia. org/component/k2/73-39-disasters-natural-and-technological/case-study-the-kader-toyfactory-fire.

19. See generally, Chris Baker \& Pasuk Phongraichit, A History of Thailand (2d. ed., 2009); see also Munger, supra note 1.

20. Rama $\mathrm{V}$ and his advisors chose European civil codes as a model because they were established in the countries with extraterritorial jurisdiction and more likely to impress them. See Tamara Loos, Subject Siam: Family, Law, and Colonial Modernity in THAiland (2006). 
(1910-25) anticipated challenges to the monarchy's legitimacy from modernization and eventual democratization by promulgating a state ideology built upon both Siamese traditions and modern democratic ideals. The three pillars of his influential formulation of a "civic religion"-Nation, Religion, Monarchy - and the concept of the king as caretaker of the people became deeply embedded in the fabric of modern Thailand's politics and civic life. Following the fall of the absolute monarchy in 1932, Thailand's rulers continued to ally themselves with the moral power of the monarchy by inculcating the "civic religion" through public education and symbolic observance.

Second, Thailand's dominating state administration has been more important than its courts in determining the power of law and the relationship between Thai citizens and the state. For much of the twentieth century and lingering still in the twenty-first, the government's role in economic development has been managed through continuing patron-client relationships between powerful bureaucrats, politicians, elites close to the monarchy, and powerful Sino-Thai entrepreneurial families. As in other Asian bureaucratic states, government guidance of economic development through these relationships, rather than through enforceable rules and policies, marginalized the role of courts and retarded development of a meaningful rule-based regulatory system. ${ }^{21}$ As private markets expanded, domestic and foreign investors concerned about favoritism and corruption increased the pressure for legal reforms such as new courts to enforce the rules protecting their investments. ${ }^{22}$

Half a century after the founding of the modern state, the overthrow of the absolute monarchy in 1932 by European-educated commoners introduced constitutionalism and a rule of law that emphasized accountability. Under the absolute monarchy, Thailand's monarchs often spoke in terms that suggested they served the people, ${ }^{23}$ but for all practical purposes the king spoke for the people. Robust accountability

21. Kanishka Jayasuriya, Introduction: A Framework for the Analysis of Legal Institutions in East Asia, in LAW, CAPITALISM AND POWER IN ASIA: THE RULE OF LAW AND LEGAL INSTITUTIONS (Kanishka Jayasuriya, ed. 1999).

22. Specialized regulatory infrastructure was added as early as the $1970 \mathrm{~s}$, including specialized civil courts, not only to improve the performance of banks and the management of trade policy but also to protect foreign private investors. A labor court was established in 1979 and an intellectual property court in 1996. See Vichai Ariyanuntaka, The Judicial System in Thailand: An outlook for a New Century, in Institute for Developing Economies, IDE-JETRO, ProceEdings OF THE ROUNDTABLE MEETing: LAW, Development AND SOCIO-ECONOMiC Changes in ASIA 3-4 (2000), http://www. ide.go.jp/library/English/Publish/Download/Als/pdf/01.pdf.

23. See David M. EnGEL, Law and Kingship in Thailand During the Reign of King Chulalongkorn (MiChigan Papers on SOUth AND SOUtheast ASIA), 113-15 (1975). 
was far from the monarchy's intent. The coup's chief architect, a lawyer trained in France, proposed creating a Council of State, like the French Conseil d'Etat, to resolve claims of governmental power abuse. In practice, however, the Council of State fell well short of creating effective accessibility and oversight, and governance through powerful networks of elites continued. ${ }^{24}$ As limited as the early Council's influence may have been in practical terms, ideas introduced in 1932 paved the way for development of academic learning in liberal constitutionalism and administrative law, and further attempts to establish administrative courts prior to the 1997 constitutional reform. ${ }^{25}$ Military partners in the 1932 coup prevailed in the long run, and accountability was placed on hold by authoritarian civilian governments and military dictators who came after.

Following World War II, the United States and World Bank made Thailand a demonstration project for capitalist development to counter the threat of communism in Southeast Asia and ultimately supported, as it was to do elsewhere during the Cold War, a military dictator who promoted development of a capitalist economy. With the aid of American funding, an expanding university system in the 1960s tapped a growing demand for upward mobility. Universities opened the countryside to students who previously knew little about their own country. New ideas about society and government flowed not only from Western-educated faculty but also from neighboring China and Vietnam where popular revolutions and confrontations with Western powers offered alternative models of change. On October 14, 1973, a student-led uprising toppled an oppressive military dictator that marked a turning point in modern Thai history. The uprising and three-year period of vibrant democracy that followed have long been remembered in Thailand as creating a generation (known as the October Generation) of leaders in social change who had embraced the value of constitutionalism and political liberalization. Of great consequence to the future evolution of Thai constitutionalism and its judiciary, a new vision of the rule of law was introduced that animated efforts of some to

24. The Council lacked well-institutionalized procedures, rules for adjudication, and trained advocates, limiting its effectiveness. See TidA CHALEECHAN, ADMinistrative COURT: ARTICLES AND ANALYSIS MADE IN THE NATIONAL LEGISLATIVE ASSEMBLy (1974) [in Thai], and Bhokin Balakula, Sequence and Origins of Attempts to Create and Propose Bills on the Establishment of Administrative Courts and Administrative Court Procedure (in Thai), ADMIN L. J. (1996).

25. See The Administrative Courts and Office of the Administrative Courts, From the Council of State to Administrative Court 230 (in Thai) (2010). Many judges and staff members of the new administrative courts had served in the Office of the Council of State, including the first President of the Administrative Court, who had previously been the Head of the Office of the Council of State. See Balakula, supra note 24. 
use law to achieve political accountability and social change. ${ }^{26}$

\section{Conflicting Constitutional Legacies}

By 1997, liberal elites as well as social movement leaders were ready to entrust the political future to a government limited by constitutional prescriptions and the will of an electorate. Concerned most about corrupt politicians who dominated rural party politics and Parliament, elite framers who chaired a constitutional drafting committee hesitated to make a profound break with Thailand's political traditions, especially the extra-constitutional authority of the monarchy. Their initial proposal omitted any mention of administrative courts, a likely accommodation to pressure from powerful bureaucrats and Justice Court judges who were protective of their jurisdiction. Instead, civil society representatives became the principal advocates for administrative courts, which ensured the courts would become part of the unfolding debate about political reform and accountability. ${ }^{27}$ Once under way, the constitutional drafting committee seriously addressed the issues of judicial independence and effective oversight of government officials. ${ }^{28}$ After years of mounting internal pressures for reform and the collapse of Thailand's economy after the 1997 Asian Financial Crisis (triggered in part by missteps at the Bank of Thailand), the committee approved a Bill of Rights, independent courts, and electoral democracy, fulfilling a Global North ${ }^{29}$ vision of liberal democracy.

A decade later in 2006 , on the threshold of political paralysis caused by the struggle between supporters and opponents of Thaksin, the king's annual address to the judiciaries of the three court systems reminded the judges of the constitution's vision of democratic politics

26. See Konokrat Lertchoosakul, The Rise AND Fall of the OCtoberists in Contemporary Thailand: Power and Conflict Among Former Left Wing Student ACtivists in Contemporary THAi POLITICS (2016).

27. See Michael Keliy Connors, Democracy and National Identity in Thailand $162-73(2003)$.

28. Const. Drafting Assemb., Const. Drafting Comm'n's Meeting Rep. (1997). The views of a 1991 constitutional drafting committee were particularly influential, and the precise structure of the administrative courts had long been discussed among academics and officials of the Petitions Council of the Council of State. See Balakula, supra note 24. While the independence of the administrative courts and Constitutional Court was discussed in 1997, interest in judicial independence redoubled after Thaksin's demise and concern about the Constitutional Court's failure to act sooner. Compare THAILAND CONST. OF B.E. 2540, 1997, \$ 3 (Thai) [hereinafter CONST. 1997] with THAILAND CONST. OF 2007 OF B.E. 2550, 2007, \$ 3 (Thai) [hereinafter CONST. 2007].

29. The term "Global North" is generally understood to refer to so-called developed countries located primarily, but by no means exclusively, the North Atlantic region. 
overseen by elites appointed to the courts. ${ }^{30}$ The message resonated among the judges and more widely among traditional elite and middle classes. ${ }^{31}$ Shortly after the king's address, the Constitutional Court, Supreme Administrative Court, and Supreme Court of Justice collaborated to drive Thaksin from power. This collaboration annulled Thaksin's latest election, removed him from office, and jailed key Election Commission members charged with fraud. These decisions ultimately accelerated political collapse and opened the door to Thailand's eighteenth military coup since 1932. ${ }^{32}$ Although many of the institutions and principles established by the People's Constitution of 1997 appear to have retained their legitimacy in popular expectations and subsequent constitutions drafted under the military's supervision, the nature and limits of a rule of law remain deeply contested by different interpretations of the 1997 political settlement. ${ }^{33}$

\section{ESTABLISHING THE ADMINISTRATIVE COURTS}

\section{The Organic Law of 1999}

Elected on a rising tide of support for constitutional rights and democratic rule, the new Parliament enacted an organic law establishing the administrative courts, giving them extraordinary power, and making them, in theory, accessible to all. ${ }^{34}$ True to the intentions of the framers and especially the goals of the people's representatives who had insisted on the establishment of administrative courts, the organic law mandated adoption of simple, low-cost procedures to maximize access to the courts by ordinary Thai citizens. As a result, filing a complaint against an official or agency required little prior preparation of claims or arguments. Court personnel are

30. Thaksin, he said, had undermined that vision and a corrupt election was no election at all. Baker \& Phongpaichit, supra note 19, at 270.

31. See id. at $272-275$.

32. This enumeration includes eleven successful and seven unsuccessful military coups but depends on precise definitions, and the number varies accordingly. See generally Baker \& Phongpaichit, supra note 19.

33. See generally Tom Ginsburg, Constitutional Afterlife: The Continuing Impact of Thailand's Postpolitical Constitution, 7 INT'L J. CONST. L. 83 (2009); Duncan McCargo \& Peeradej Tanruangporn, Branding Dissent: Nitirat, Thailand's Enlightened Jurists, 45 J. CONTEMP. ASIA 419 (2015).

34. See Act On Establishment of Administrative Courts and Administrative Court Procedure [Organic Law], B.E. 2542 (1999) (Thai) (administrative courts have broad jurisdiction over government decisions and policies, equivalent to those of European and American courts, and more remedial power at their disposal than the French courts on which they were modelled); see also Leyland, supra note 9, at 237-38. 
directed to assist in drafting a complaint and to investigate the facts alleged. Examination of witnesses is conducted by the administrative court judge, which shifts the burdens of trial to the court and eliminates, at least on paper, a need for legal representation. ${ }^{35}$ Easy access to a process that calls government officials to account not only runs counter to the experience of most citizens but also violates deeply embedded traditions of conflict avoidance and deference that may be on the wane but remain strong among many Thai citizens. ${ }^{36}$

\section{Structural Limits of Administrative Courts}

If the courts' organic law was clearly intended to facilitate access to judicial oversight, other elements of court structure and organization directly or indirectly limit the courts' influence in policy-making and politics. The comparative political independence of the administrative courts is, in part, an artifact of their relative insulation from political conflict. For example, the Constitution of 2007 barred administrative court review of agencies expressly granted power by the Constitution. ${ }^{37}$ Further, administrative court decisions infrequently bear on the constitutional allocation of powers. ${ }^{38}$ The vast majority of their cases are decided under statutory law rather than constitutional rules or principles governing political structure. ${ }^{39}$ The limited jurisdiction has

35. See Organic Law, supra note $34, \$ \$ 54-66$; see also id. at $\$ 52$ (the organic law allows administrative courts to accept cases defending the public interest regardless of the statute of limitations).

36. As simplified as access is, the court's decision processes are complex. Each case is assigned a panel of judges. In addition, a Recording Judge is appointed to examine the case independently, presenting conclusions to the panel after it has completed its own analysis. This procedure is facially intended to counter possible panel bias, but because the Recording Judge is appointed by the highest court officials, may also be intended to check extreme acts of judicial independence. See Leyland, supra note 9, at 237-38.

37. A constitutional revision in 2007 barred administrative courts from oversight of agencies with constitutional authority, including the Election Commission which was suspected of corruption under Thaksin. See CONST. 2007 supra note 28 , at $\$ 223$.

38. See id at $\$ 199$; see also Leyland, supra note 9 , at 238 (jealous protection of the civil courts' jurisdiction may explain the fact administrative courts must yield to other courts with jurisdiction over a case and, if in doubt, submit the question to a special judicial panel for resolution).

39. While Thai legal education focuses on principles of strict statutory construction, Thai jurisprudence permits use of a broad range of interpretive principles. Kittisak Prokati, Faculty of Law, General Principles of Legal Usage and Interpretation [in Thai], In Memorial of Professor Jitti Tingsabhat Academic Seminar, at 4 (Mar. 29-30, 2008) (transcript on file with authors). In practice, the Thai Justice Courts have not used their ample power to promote a robust culture of rights. $I d$. "Justice" has long meant more than the letter of law according to Thai legal historians. Kittisak Prokati, Thai Law, A Cultural Perspective [in Thai], The National Seminar, at 8 (The Office of National Culture, Apr. 20- 
sidelined its judges in most of the politically controversial cases of constitutional interpretation.

The Supreme Administrative Court has decided a handful of sensitive decisions involving political parties or the prime minister, and while some of its decisions could be characterized as favoring powerful politicians, royalist elites, or the military, many other important decisions cannot.40 After expansion of the Constitutional Court's jurisdiction over elections in 2007, that court played a greater role in partisan politics. In contrast, the Supreme Administrative Court has been an infrequent player in partisan conflict and has been targeted less frequently by political critics. ${ }^{41}$ On the contrary, administrative court judges have expressed faithfulness to their task as guardians against government wrongdoing, notwithstanding the pull of Thailand's cultural traditions of accommodation and conflict avoidance. ${ }^{42}$ Some scholars have suggested that judicial ideology explains the administrative courts' greater apparent faithfulness to the rule of law, ${ }^{43}$ but judges on both courts are from similar backgrounds and are chosen by similar, elitecontrolled processes. ${ }^{44}$ Ideology, though undoubtedly influential in any

22,1995 ) (transcript on file with authors). In a 2008 seminar on the administrative courts, Supreme Administrative Court President Ackaratorn expressed his belief in the judiciary's commitment to protection of rights. Ackaratorn Chularat, A New Role for Administrative Courts of Thailand [in Thai], in Rechstaat in Thai Society Annual Seminar, at 11 (Dec. 16, 2008) (transcript on file with authors). In practice, the Thai Justice Courts have not used their ample power to promote a robust culture of rights. See Michael Kelly Connors, Ambivalent About Human Rights: Thai Democracy, in HuMAN RIGHTS IN ASIA 103 (Thomas W.D. Davis \& Brian Galligan, eds., 2011).

40. See Leyland, supra note 9, at 242-246.

41. Senior academics and judges have suggested that allegations of bias themselves may reflect the increasingly partisan political climate. Somkit Lertpaithoon, A New Role for Administrative Courts of Thailand [in Thai], in Rechstaat in Thai Society Annual Seminar, at 60 (Dec. 16, 2008) (transcript on file with authors).

42. Administrative court judge Prasart Pongsuwan expressed this view. "The Thai Supreme Administrative Court is considered new, and since its inception, Thailand has been under one-sided government. Therefore, it could be mistakenly perceived that the Administrative Court is an opponent of Thaksin's administration ... If you wait long enough, you will see that the Court is the enemy of every government ... There is no such thing as a 'new role' for the administrative courts. The role has always been the same old role which is controlling the executive branch or government action. This is something that governments do not like. This job is considered a sin [แาปกรรม] to those working in the administrative court. Before I came to be a judge at the administrative court, I had no idea what it would be like. But after I became an administrative judge, I now know what that role is." Id. at 38 .

43. See Duncan McCargo, Competing Notions of Judicialization in Thailand, 36 CONTEMP. SE. ASIA 417, 423 (2014).

44. Compare Const. 1997, supra note 28, $§ 277$, with Const. 2007, supra note 28 , $\S$ 204, 206. See also Organic Law, supra note $34, \S \S 13,18$. In addition, administrative court nominations are made by a select body serving as the Judicial Commission of the 
court system, does not necessarily explain differences in political function. ${ }^{45}$ Yet, here too, there is no sharp division between the responsibilities of the Constitutional Court and administrative courts. While administrative courts have a more limited mandate, in principle, they extend the rule of law to the highest levels of government.

Independent of framers' intentions and judicial ideology, institutional structure limits the administrative courts' impact on the routines and customs of policy-making in powerful ministries. Thai ministries present special challenges for judicial oversight. Within many ministries, personal influence still commands greater deference from officials than court decisions. 46 As a novel institution struggling for a place within Thailand's traditions of political and social influence, however, Thai courts have limited political power support for their legal authority. The influence of international investors empowers friendly politicians and domestic ministries with jurisdiction over business and trade to the detriment of ministries and the courts that oversee domestic policies protecting communities or the environment. ${ }^{47}$ Policy-

Administrative Courts. See ConsT. 2007, supra note 28, $\$ 226$, while Constitutional Court nominations are subject to oversight by a committee of the Senate, a body specifically constituted to offset populist political pressure. See CONST. 2007, supra note 28, § 206.

45. See Frank Upham, Mythmaking in the Rule-of-Law Orthodoxy, in Promoting THE Rule of LaW Abroad: In Search of Knowledge 75, 75 (Thomas Carothers ed., 2006). Further, notwithstanding perceptions of news media to the contrary, the U.S. State Department reports that, except in cases the military junta has identified as matters of national security, a label it applies quite liberally, Thai courts enforce the law and respect rights to a fair trial, suggesting that on the whole the judiciary has retained its independence. See U.S. DeP'T of State, Bureau of Democracy \& H.R. AND LaB., THAILAND 2017 HUMAN RIGHTS REPORT 9 (2017), https://www.state.gov/documents /organization/277365.pdf.

46. Favoritism by Thai officials, also termed corruption, is widely reported on business security websites and is a factor in Thailand's relatively poor ranking by Transparency International. See Thailand Corruption Report, GAN BUSINESS ANTI-CORRUPTION PORTAL, (last updated Sept. 2017), https://www.business-anti-corruption.com/countryprofiles/thailand/; see also Corruption Perceptions Index, TRANSPARENCY InTERNATIONAL (Jan. 25, 2017), https://www.transparency.org/news/feature/corruption_perceptions_ index_2016\#table. Reports and rankings are based on opinions and public perceptions rather than actual incidents, although there is no shortage of anecdotes about corruption at the highest levels, including reports involving high ranking members of the current military regime, which has claimed that ending corruption is an important part of its mission. See Pavin Chachavalpongpun, The Latest Thai Corruption Scandal is Causing Problems for the Ruling Junta, WASH. POST, (Jan. 23, 2018), https://www.washingtonpost. com/news/democracy-post/wp/2018/01/23/the-latest-thai-corruption-scandal-is-causingproblems-for-the-ruling-junta/?noredirect=on\&utm_term=.ba6ed5a63f79 (Thailand's slow moving administrative court process may also motivate attempts to influence officials directly).

47. For an illuminating case study of the capacity of politicians, international business and business-oriented ministries to thwart a path-breaking environmental remedy orders 
making ministries often claim they lack the power and budget to enforce policies directly and that they must rely on other ministries or local officials to carry them out. ${ }^{48}$ Thai ministries established a century or earlier under the control of powerful royal overseers continue in the modern era to be insular, competitive, and unresponsive. ${ }^{49}$

Realities on the ground that negate the value of the courts' simplified procedures must be added to the legacies of institutional structure and jurisprudence that influence the courts' emerging capacity to uphold the rule of law. Despite ambivalent intentions of a divided elite and institutional barriers to effective use of the courts, rising caseloads show Thai citizens have responded to the invitation to challenge government actions. If administrative courts have limited power to enter into political controversies that concern the structure of state power, they seem to have been effective in a range of more limited controversies with ministry officials and less visible, but more numerous, local government controversies. ${ }^{50}$

\section{THAI ADMINISTRATIVE COURTS AT WORK}

\section{Who Uses the Courts?}

There are both cultural and practical barriers to mobilizing courts in a society where historically courts have been viewed remote and law not well understood. Most ordinary Thai citizens have little knowledge of the century-old civil courts and avoid using them to resolve conflict. Administrative courts are new and unfamiliar to most lawyers. As we explain further in Part V, after overcoming these barriers, even a simple and relatively uncontroversial claim may require persuasion to move a bureaucratic and, in some regions, overworked court staff to proceed

by the administrative courts see Sarah Bishop. The Thai Administrative Court and Environmental Conflicts: A Case Study of Map Ta Phut, Rayong (2011) (published MA thesis) (on file with the Australian National University).

48. Interview with the former Deputy Director General of the Pollution Control Department, Dr. Vijarn Simachaya (Dec. 25, 2012); see also The Nation, Court Overturns Massive Compensation Ruling for Klong Dan Project, THE NATION (Mar. 7, 2018, 1:00 PM), http://www.nationmultimedia.com/detail/national/30340348.

49. See James Ockey, State, Bureaucracy, and Polity in Modern Thai Politics, $34 \mathrm{~J}$. CONTEMP. ASIA 143, 146 (2004).

50. Thailand first allowed class actions in 2015. See Act TO AMEND THE CIVIL PROCEDURE CODE, B.E. 2558 (2015) [hereinafter "The Act"]. Environmental litigation in the civil courts has become the testing ground. See Aaron Le Marquer, Thailand Certifies First Class Action, TillekE \& GibBins (Feb. 27, 2018), https://www.tilleke.com/resources/thailand-certifies-first-class-action. 
with the case and persist through multiple judicial hearings. ${ }^{51}$ Who, then, mobilizes the authority of the administrative courts?

\section{Rates of Litigation}

Steadily rising administrative court caseloads show that the administrative courts have been well-used from their inception and that their attraction has increased. Since the administrative court system opened its doors in 2001, it has accepted thousands of new cases per year, exceeding 10,000 new cases in 2016. Diagram 1 shows the number of new cases filed in the administrative courts from 2001 to 2016 . For the first ten years, the administrative courts averaged less than 5,000 new cases each year, but since 2011 new cases have been filed at an increasing rate and have averaged more than 8,500 over the last seven years.

Diagram 1: Number of New Administrative Court Cases by Year 20012016

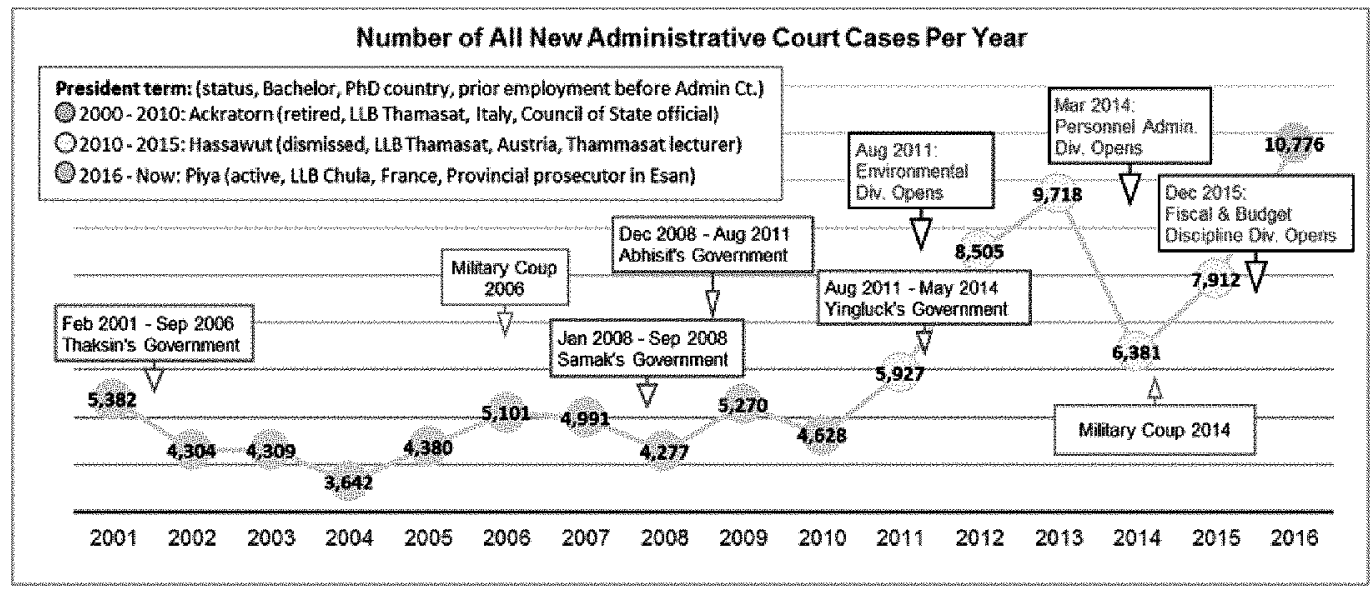

Source: All tables and diagrams based on data from the Administrative Court Website, http://www.admincourt.go.th/admin court/site/03 stattotal.html (last visited on Feb. 13, 2018).

51. A general description of the administrative court litigation process can be found in การนั่งพิจารณาคดี, ตุลาการศาลปกครอง, การพิพากษาคดี [Administrative Case Trial, Administrative Judges: Deciding Administrative Cases] [in Thai], available at https://oer.learn.in.th/search_detail/ZipDownload/53641. Our characterizations in the text were supported by interviews with administrative court litigators conducted between 2009 and 2017 . 
Litigation rates per hundred thousand citizens, which are a more meaningful baseline for comparisons, tell the same story (see Diagram 2).

Thailand experienced frequent political disruptions over this time period, but there is no evidence connecting political disruption to fluctuations in the rate of litigation. Neither disruptive political succession nor violent protest bear an obvious relationship to fluctuations plotted in Diagrams 1 and 2. Three such events occurred between 2001 and 2010: the 2006 Military Coup, removal of a Thaksin supported Prime Minister in 2008, and extreme political violence associated with suppression of a Red Shirt (pro-Thaksin) protest in 2010. The overall litigation rate steadily rose over the entire period. Political disruptions continued between 2011 and 2017. Prime Minister Yingluck's term was disrupted by protests and ended in 2014 when she was removed from office by court decision, coincident with a second military coup. In contrast to the first period, litigation rates rose sharply and unevenly, but without a clearer connection or rationale, it would be hard to associate these changes with Thailand's political disruptions. Over the entire period, important changes occurred in the structure of the administrative courts, and we consider this a promising explanation for changes in use of the courts. ${ }^{52}$

Diagram 2: Litigation Rates by Year (per 100,000 citizens) 2001-2016

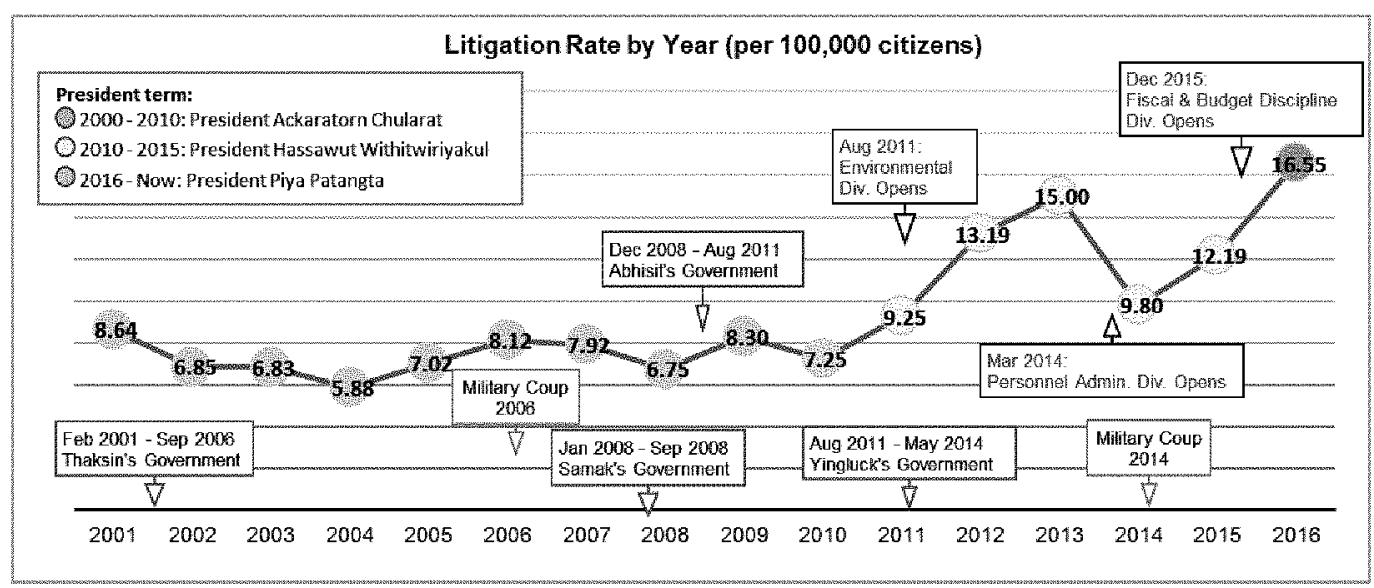

52. Over the span of sixteen years, the Supreme Administrative Court has been led by three different presidents, Ackaratorn Chularat, Hassawut Withitwiriyakul, and Piya Patangta, all of whom have been viewed as "activists" for their dedication to upholding the rule of law and were members of the majority ruling against the government in the Map Ta Phut case. See Bishop, supra note 47. 


\section{Types of Cases}

Much government activity concerns policies that affect the entire population, such as maintaining a power grid, conducting foreign affairs, or creating policies for environmental protection. Most Thai administrative court litigants, however, have a specific relationship with government defined by: government employment; a government contract; a franchise, license, lease, or concession; enrollment in a public university; or use of government health care. It is little surprise, then, that most cases are brought by individuals with such relationships (see Diagram 3). Personnel cases are most numerous and ranged up to 37 percent of the entire case load in 2009 (see Diagram 3), followed by property repossession and similar lease or contract-related cases and regulation of buildings and land use. Not only do these litigants have a clearly defined stake in a relationship with the Thai government but they are also likely to be wealthier and more educated than the average Thai citizen and have greater confidence dealing with officials. ${ }^{53}$

\section{Diagram 3: Percentage of Cases by Type by Year 2001-201554}

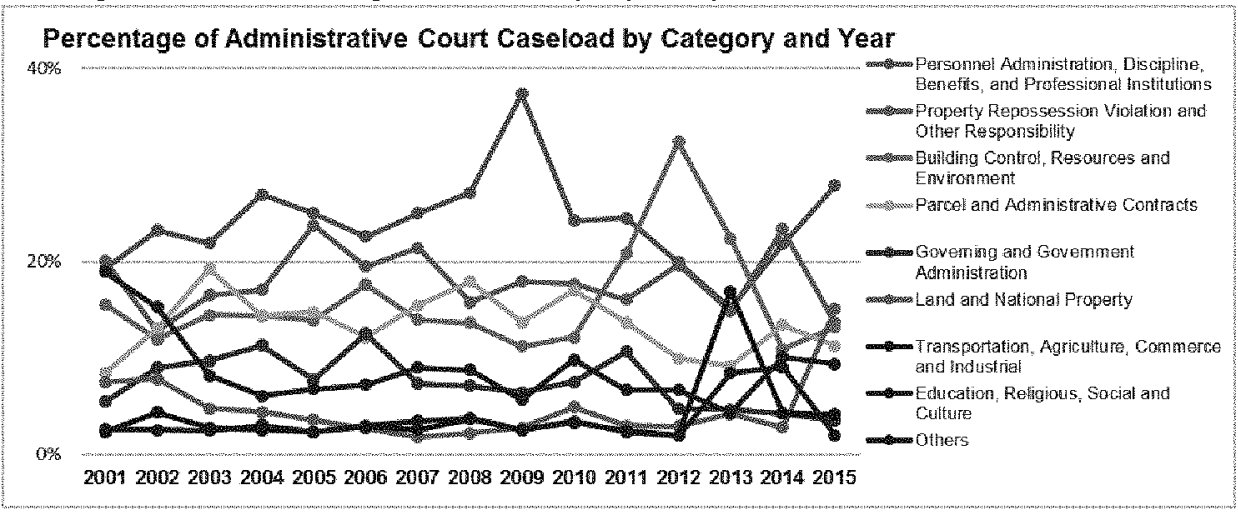

53. For example, frequent litigants such as government employees and local government officials may view the courts' plaintiff-friendly procedures as little more than a grievance mechanism for their continuing relationship with a government institution.

54. Prior to 2016, new cases submitted to the Administrative Court were reported in nine broad categories. In December 2015, a tenth category was added called "Fiscal and Budget Discipline." At the end of 2016 , only sixteen new cases were reported under this new category, for consistency we have combined these with the category "Others" in 2016; see Judicial Review Chart Entirety Since Opening, THE ADMINISTRATIVE COURT (current through Aug. 31, 2018), http://www.admincourt.go.th/admincourt/site/03stattotal.html. 
Tables 1 \& 2: Number of Cases by Type by Year 2001-2016

\begin{tabular}{|l|l|l|l|l|l|l|l|l|}
\hline Topic & 2001 & 2002 & 2003 & 2004 & 2010 & 2006 & 2007 & 2008 \\
\hline $\begin{array}{l}\text { Personnel Administration, } \\
\text { Discipline, Benefits, and } \\
\text { Professional Institutions }\end{array}$ & 1,033 & 1,001 & 944 & 980 & 1,094 & 1,151 & 1,248 & 1,161 \\
\hline $\begin{array}{l}\text { Property Repossession Violation } \\
\text { and Other Responsibility }\end{array}$ & 1,080 & 553 & 710 & 620 & 1,039 & 993 & 1,070 & 674 \\
\hline $\begin{array}{l}\text { Building Control, Resources and } \\
\text { Environment }\end{array}$ & 838 & 512 & 622 & 523 & 608 & 899 & 696 & 582 \\
\hline $\begin{array}{l}\text { Parcel and Administrative } \\
\text { Contracts }\end{array}$ & 455 & 562 & 831 & 524 & 647 & 618 & 770 & 768 \\
\hline $\begin{array}{l}\text { Governing and Government } \\
\text { Administration }\end{array}$ & 293 & 386 & 419 & 412 & 338 & 638 & 365 & 305 \\
\hline Land and National Property & 402 & 336 & 205 & 161 & 157 & 138 & 90 & 95 \\
\hline $\begin{array}{l}\text { Transportation, Agriculture, } \\
\text { Commerce and Industrial }\end{array}$ & 124 & 187 & 119 & 92 & 101 & 145 & 130 & 157 \\
\hline $\begin{array}{l}\text { Education, Religious, Social and } \\
\text { Culture }\end{array}$ & 138 & 109 & 107 & 110 & 100 & 151 & 173 & 160 \\
\hline Others & 1,019 & 658 & 352 & 220 & 296 & 368 & 449 & 375 \\
\hline
\end{tabular}

\begin{tabular}{|l|c|c|c|c|c|c|c|c|}
\hline Iopie & 2009 & 2010 & 2011 & 2012 & 2013 & 2014 & 2015 & 2016 \\
\hline $\begin{array}{l}\text { Personnel Administration, } \\
\text { Discipline, Benefits, and } \\
\text { Professional Institutions }\end{array}$ & 1,969 & 1,122 & 1,451 & 1,693 & 1,474 & 1,392 & 2,207 & 2,563 \\
\hline $\begin{array}{l}\text { Property Repossession Violation } \\
\text { and Other Responsibility }\end{array}$ & 945 & 818 & 950 & 1,672 & 1,440 & 1,490 & 1,079 & 2,236 \\
\hline $\begin{array}{l}\text { Building Control, Resources and } \\
\text { Environment }\end{array}$ & 589 & 562 & 1,232 & 2,754 & 2,179 & 697 & 1,043 & 1,372 \\
\hline $\begin{array}{l}\text { Parcel and Administrative } \\
\text { Contracts }\end{array}$ & 721 & 787 & 812 & 842 & 887 & 857 & 889 & 1,361 \\
\hline $\begin{array}{l}\text { Governing and Government } \\
\text { Administration }\end{array}$ & 337 & 347 & 631 & 400 & 451 & 270 & 280 & 396 \\
\hline
\end{tabular}




\begin{tabular}{|l|c|c|c|c|c|c|c|c|}
\hline Land and National Property & 145 & 227 & 176 & 246 & 406 & 180 & 1,192 & 1,029 \\
\hline $\begin{array}{l}\text { Transportation, Agriculture, } \\
\text { Commerce and Industrial }\end{array}$ & 133 & 153 & 143 & 166 & 1,643 & 275 & 325 & 456 \\
\hline $\begin{array}{l}\text { Education, Religious, Social and } \\
\text { Culture }\end{array}$ & 132 & 158 & 136 & 163 & 819 & 576 & 154 & 150 \\
\hline Others & 299 & 454 & 396 & 569 & 419 & 644 & 743 & 1213 \\
\hline
\end{tabular}

Regional differences in litigation rates may be related to the geographic distribution of particular types of cases. The central region, containing Bangkok and its suburbs, is the location of the largest government agencies and their supporting services, typically by far the highest litigation rates of any region. (See Diagram 4). Differences in regional litigation rates may also have to do with the administrative court systems' changing structure.

Diagram 4: Litigation rates by Region by Year 2001-2016

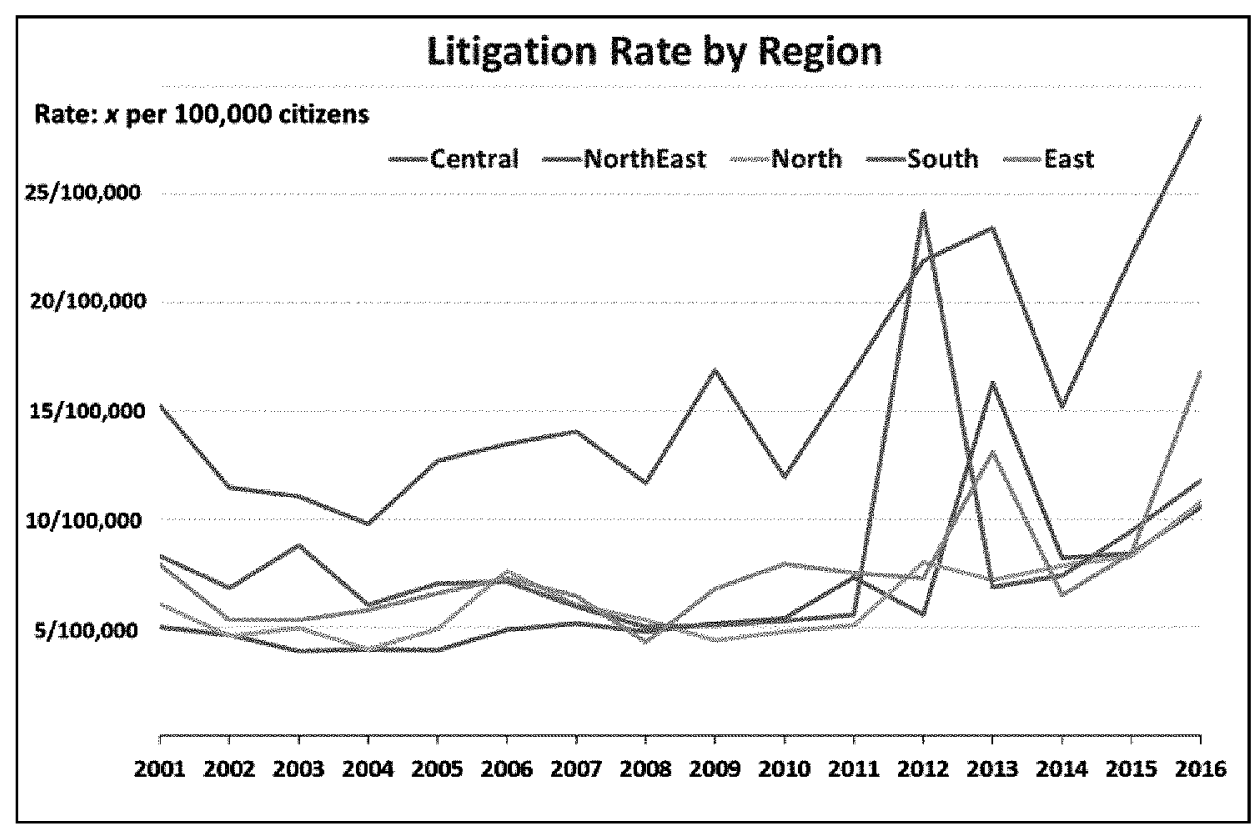

Court System Structure

The administrative court system opened in 2001 with just a fraction of the authorized regional courts in place. The Administrative Court 
Legislative Act of 1999 authorized sixteen regional first-instance administrative courts throughout Thailand-two in the central region, six in the northeast region, one in the east, three in the north, and four in the south. ${ }^{55}$ The first set of regional administrative courts opened in 2001 in Chiang Mai (north), Songkhla (south), and Nakorn Ratchasrima (northeast). ${ }^{56}$ New regional courts opened every few years, and currently, eleven of the projected sixteen regional courts have been established. ${ }^{57}$ The dispersion and small number of regional administrative courts created unanticipated barriers to litigation. Even though accessible administrative courts were established in the expectation that litigants would present their own claims and give evidence at subsequent hearings, a litigant of modest means found travel and board costs of litigation at a location far from home a great burden. ${ }^{58}$ Slow expansion of the regional court system has undoubtedly reduced these costs for some litigants, which may be a factor in the gradual upward trend in the rate of litigation.

Between 2011 and 2016, three specialized divisions were created: the Environmental Division (2011), the Personnel Administration Division (2014), and the Fiscal and Budget Discipline Division (2015). ${ }^{59}$ In 2014 when the Personnel Administration Division was established, then president of the Supreme Administrative Court, Dr. Hassawut Withitwiriyakul, suggested that the specialized division was a response to the large volume of personnel cases, which often creates a bottleneck that needs to be processed quickly. ${ }^{60}$ The new division decreased delays

55. See Organic Law, supra note 34 , at $\$ 94$.

56. See Administrative Court Structure, THE ADMINISTRATIVE COURT (last visited Jan. 12, 2018), http://www.admincourt.go.th/admincourt/site/01structure.html.

57. Other regional courts opened in 2002 (Khon Kaen and Phitsanulok), 2003 (Rayong) and Nakorn Srithammarat), 2010 (Udon Thani), 2011 (Ubon Ratchathani), 2015 (Phetburi), and 2016 (Nakorn Sawan). See id.

58. The authors conducted several interviews with litigators whose clients fund travel and maintenance to attend hearings-a nearly insurmountable burden. See Part V.

59. See Announcement on Establishment of the Environmental Division, 128 RoYAL Thai Gov't GazeTTE, Part 54a B.E. 2554, July 4, at 16; Announcement of Establishment of the Personnel Administration Division, Vol. 131 Royal ThaI Gov'T GAzETTE, Part 12a, B.E. 2557 Jan 24, at 4; and Announcement of Establishment of the Fiscal and Budget Discipline Division, Vol. 132 Royal Thai Gov't GazeTte, Part 105a B.E. 2558, Nov. 6, at 16.

60. See Office of the Administrative Court, Administrative Court's Performance Update on 14th Anniversary, ADMINISTRATIVE COURT News, (Mar. 6, 2015), http://admincourt.go.th/ADMINCOURT/upload/webcms/Oldnews/attach/news_attach/2015 103/21.pdf; Sakrin Khemtong, 13th Anniversary of Administrative Court - Too Many Illegal Transfer Cases, KRUnGTHeP Business News, (Mar. 14, 2014), http://www. bangkokbiznews.com/news/detail/568669 (the Division has adopted procedures permitting the head of the panel assigned to the case to issue interim orders that allow the 
but also contributed to a sharp rise in the amount of personnel litigation (see Diagram 5). Yet volume alone may not have triggered this decision. Personnel cases dominated the court docket from the beginning, but immediately prior to opening its new division, the administrative courts were required to decide several well-publicized cases involving high profile officials appointed by a prior administration. By opening a specialized personnel division, the Judicial Council of the Administrative Courts may have hoped to limit future political fallout through swift resolution by judges skilled in routine processing of personnel matters. ${ }^{61}$ The judiciary's sensitivity to the political consequences of delay is also underscored by its reasons for establishing the Fiscal and Budget Discipline Division in 2015. Only sixteen cases were filed in this division in 2016, but judges who have spoken publicly about the reasons for the new division have said that the mishandling of funds (identified by the Office of Auditor General) created politically sensitive controversies over corruption, budget allocation, and political reputation that must be resolved quickly. 62

government to function or preserve an employee's rights while a final resolution is reached).

61. The especially sensitive case of Thawil Pleinsri, a political appointee of the previous regime and transferred by Prime Minister Yingluck, Thaksin's sister, shortly after she took office, was decided just a few days before Personnel Administration Division opened on March 10, 2014. See Case Closed on Thawil Pleinsri's Case: Opening of Administrative Court's Personnel Administration Division, MANAGER ONLIne, (Mar. 19, 2014), https://mgronline.com/crime/detail/9570000031053; Sakrin Khemtong, 13th Anniversary of Administrative Court - Too Many Illegal Transfer Cases, KRUNGTHEP BUSINESS NEWS, (Mar. 14, 2014), http://www.bangkokbiznews.com/news/detail/568669.

62. As administrative court Judge Wisanu Wanranyu explained, "The new division is intended to serve as an 'Express Lane' to help expedite this type of case. Otherwise this type of case will be considered a General Administrative case, and it would be some time before the trial could begin." Keasinee Tangkiew, The Fiscal and Budget Discipline Division of the Administrative Court - A New Mechanism to Fight Corruption, KOMCHADLUEK, (Dec. 5, 2015), http://www.komchadluek.net/news/politic/218064. 
Diagram 5: Number of Personnel Administration and Environmental Cases by Year 2001-2016

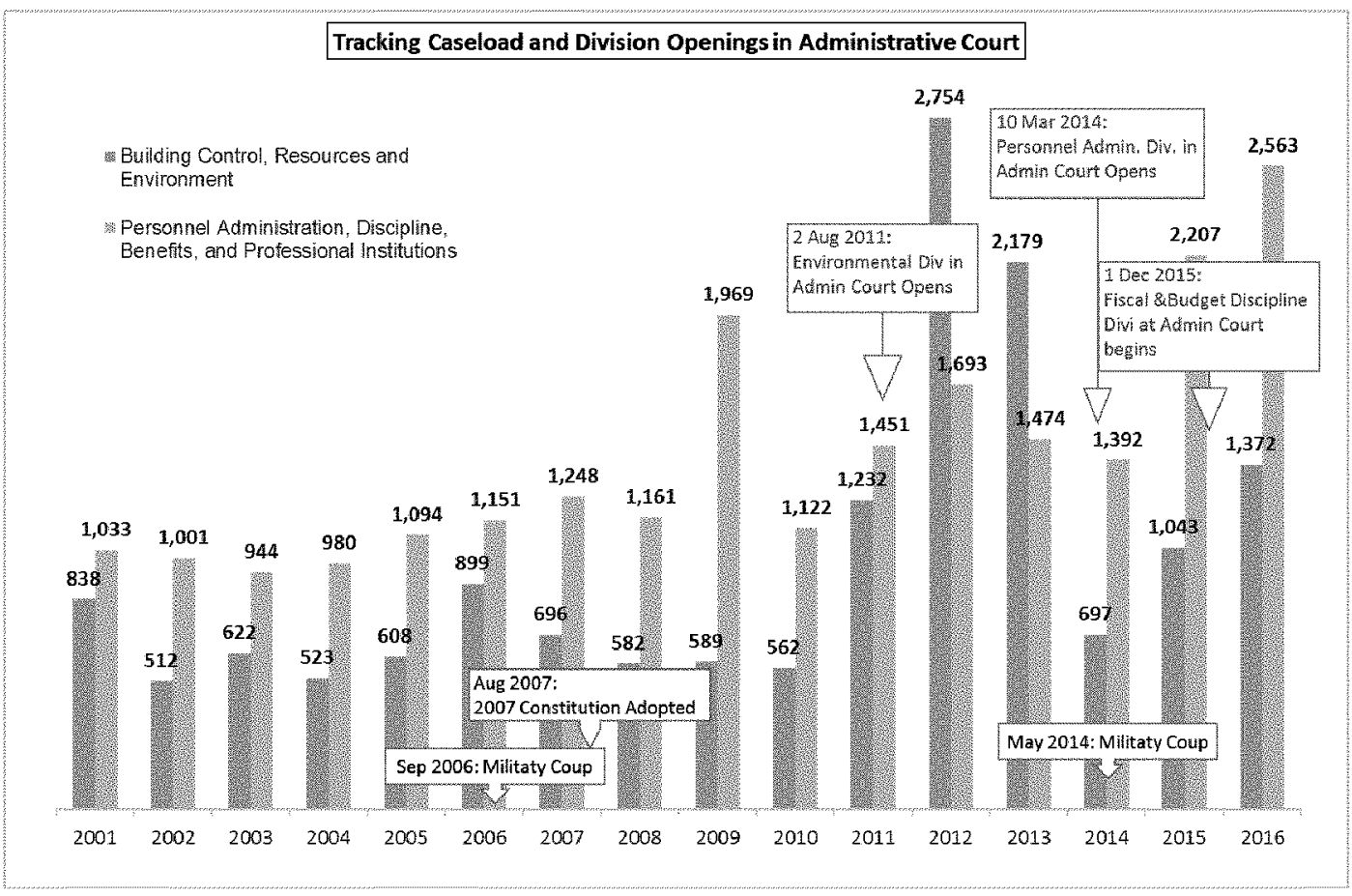

Environmental Litigation

Environmental cases, like personnel cases, have been slowly increasing in number (and rate), but unlike the latter, the sharp increase in environmental cases occurred after the opening of the new Environmental Division in 2011 (see Diagrams 5 \& 6). The timing suggests a very different interaction between the administrative courts and their social and political environment. In 1992, Thailand adopted environmental protection laws modeled on international standards, but the law was seldom enforced due both to practical barriers to civil court litigation for damages and to the absence of an effective means of oversight. Accessible administrative courts offered a solution to both problems. It is unsurprising that non-governmental organizations (NGOs) representing rural communities affected by Thailand's ambitious land and resource development projects were among the primary advocates for the courts and, in some cases supported by the same NGOs, among the first plaintiffs in environmental litigation in the 
administrative courts. Environmental litigation by other groups brought together by the possibility of litigation is a new phenomenon examined in Part $V$.

As early as 2005, after a U.N. Development Project meeting in Bangkok to promote more environmental courts, Thailand's Justice Courts established a specially trained Green Bench. By contrast, administrative court judges received little specialized training in handling complex environmental claims until establishment of the Environmental Division in 2011.63 The catalyst was likely a firstinstance administrative court's electrifying decision in 2009 that temporarily shut down the Map Ta Phut industrial estate, one of Thailand's largest, due to the government's alleged failure to enforce statutory air quality standards and to implement a constitutional provision requiring community consultation. The case and its aftermath had two consequences: an immediate upsurge in environmental cases soon after the decision and exposure of evidentiary and jurisprudential weaknesses in a prestigious panel's handling of the case. Although the decision was hailed within Thailand and abroad as a leading edge of the rule of law in Thailand, ${ }^{64}$ some domestic critics claimed to find numerous weaknesses in the statutory and constitutional interpretations underlying the decision, ${ }^{65}$ and much of the holding's sting was removed by the same court's rapid turnaround. The same intermediate court exonerated most of the companies a year later, and the intermediate court's decree was weakened further on appeal to the Supreme Administrative Court. Both consequences were likely factors in the decision to create the Environmental Division.

63. Bishop, supra note 47 , at 20.

64. See Dieter C. Umbach, Professor, Remarks made extemporaneously at the 4th International Conference on "Law in the Changing World" at Thammasat University (Dec. 9, 2009).

65. See Interview with Worachet Pakeerat: "Extreme" view against the Supreme Administrative Court's Decision on Map Ta Put, PRACHATAI (Dec. 12, 2009) https://prachatai.com/journal/2009/12/27076. 
Diagram 6: Environmental Cases by Year 2001-2016

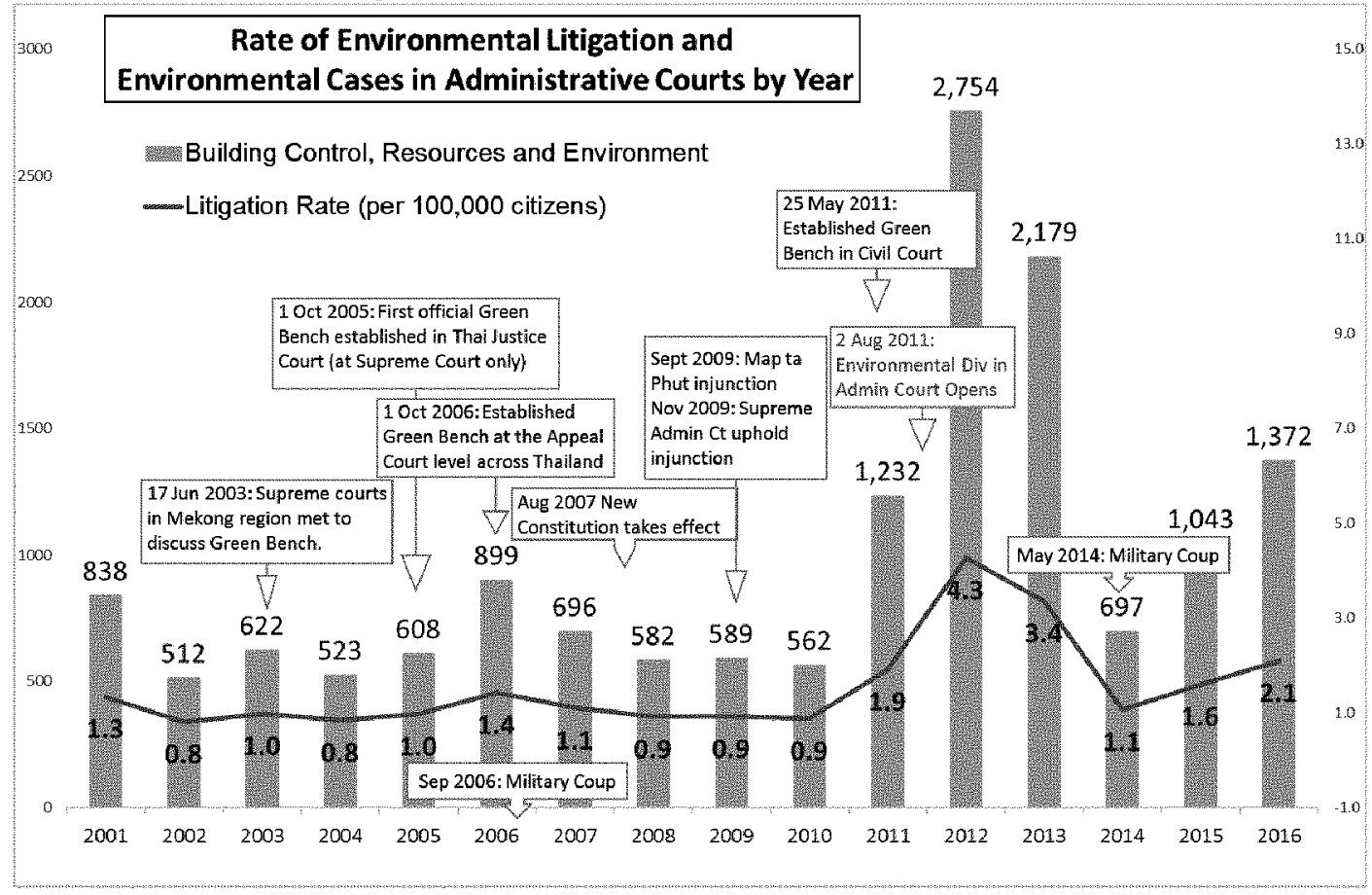

\section{Decisions with Consequences}

Although the numbers and types of cases provide some sense of the administrative courts' presence and influence, we have presented no direct evidence that they are an effective means for responding to claims against the government.66 In addition to the 2010 Map Ta Phut Industrial Estate decision mentioned earlier, a number of high profile decisions reversing important government decisions or programs have received favorable attention from scholars. ${ }^{67}$ Although the most notable of these were cases brought against Thaksin-era privatization policies and therefore subject to partisan interpretation, a stronger case for the non-partisan influence of the courts can be made by noting that governments (prior to the 2014 coup) controlled by pro-Thaksin and anti-Thaksin politicians have reversed high-level administrative appointments.

66. Part $\mathrm{V}$ of this article adds some depth to our argument that administrative courts have mattered.

67. See Leyland, supra note 9, at 242-48. 
During the period between the military coups in 2006 and 2014, conflict between political factions became intense, often spilling over into street violence. Holdover incumbents in important bureaucratic positions were targeted for transfer by incoming regimes. Three high profile transfer cases during this period support the perception of administrative court political independence.68 Each case involved demoting a high ranking official appointed by the prior political regime, and each tested the limits of executive discretion to decide based on political ideology while ignoring the laws governing transfers. ${ }^{69}$ All three cases were decided against the incoming regime that attempted to remove the official. The administrative court has posted numerous notable decisions holding national or local officials accountable on its website with brief descriptions of the remedies granted. ${ }^{70}$ These cases suggest that the administrative courts can resist pressure from elected politicians.

A measure of the administrative courts' resistance to institutional pressure from a different direction, Thailand's powerful bureaucrats, is the court's growing use by businesses to challenge policy decisions. In the past, litigation by businesses challenging power of bureaucrats or politicians was rare, unlike the United States where there is a long history of corporate litigation contesting government regulation..$^{71}$ Presently, businesses in Thailand seem increasingly willing to litigate,

68. See Jadul Apichartbutr vs. PM Samak in 2008 (Supreme Administrative Court Ordered to Return Jadul's Position), MANAGER ONLINE (Jul. 25, 2011), http://www.mgronline.com/Politics/Viewnews.aspx?NewsID=9540000091717; Peerapol Tritasawit vs. PM Abhisit in 2009 (Administrative Court Ruled Illegal Transfer of Peerapol Made by Abhisit and Suthep), MANAGER ONLINE (Nov. 19, 2012), http://www.mgronline.com/Politics/ViewNews.aspx?NewsID=9550000141180; Thawil Pleinsri vs. PM Yingluck in 2011 (Case Closed on Thawil Pleinsri's Case: Opening of Administrative Court's Personnel Administration Division), MANAGER ONLINE (Mar. 19, 2014), https:/mgronline.com/crime/detail/9570000031053 (although each case was significant domestically, the third received the greatest attention in the international press because it involved Prime Minister Yingluck, Thaksin's sister, at a time of increasing resistance to her Red Shirt government, and shortly before overthrow of her government by the military).

69. The statutory law permitted reassignment but only to a position commensurate with the rank and experience of the official, a principle the court said was violated in each case. For a summary of all three cases see Personnel Administrative Cases (JadulPeerapol-Thawil) Decided on Same Principle, ADMINISTRATIVE COURT http://admincourt.go.th/admincourt/upload/webcms/Academic/Academic_150216_142145.p df (Last Visited Jul. 10, 2018).

70. See Resolution of the Judicial Council of the Administrative Courts Regarding "Hot Suits," ADMINISTRATIVE COURT, http:/www.admincourt.go.th/admincourt/upload/webems/ News/News_230516_100755.pdf.

71. See Adam Winkler, We the Corporations: How American Businesses Won THEIR Civil RIGHTS (2018). 
not only defensively but also affirmatively to limit bureaucrats' use of discretionary powers. ${ }^{72} \mathrm{~A}$ third source of institutional pressure is the ever-present military and the current junta. While legal confrontations with the military and police have taken place mostly in the Justice Courts and military courts in cases in which defendants have been accused of political crimes, administrative courts have been willing to rule against the military government in a few cases within their jurisdiction. ${ }^{73}$

\section{CONTENTIOUS ENVIRONMENTAL LITIGATION}

Klity Creek 1967-2017

In 1967, Komol Lead Concentrates Co. Ltd. opened its mine in Kanachanburi Province at a location deep in the Thugyai-Nareasuan Forest and demped its lead bearing waste in Klity Creek. The Creek's wildlife, vegetation, and clean water sustained the way of life of the Karen, one of Thailand's isolated ethnic minorities living along its banks. In 1998 as the NGO movement expanded, organizers came to the village and assisted its inhabitants in contacting the media to make Karen's grievances public. Thai ministries showed up in force. The Department of Mineral Resources temporarily closed the mine. The Pollution Control Department (PCD) took samples and banned further use of the creek water, which cut off the Karen from their livelihood. An inter-agency committee resolved that remediation should be undertaken, but nothing was done.

The Karen, with NGO assistance, brought the dilemma to the postconstitutional network of lawyers for social causes. A civil court case was filed in 2003 by 151 Karen who sought damages for injuries dating from 1967, future medical costs, and the cost of sustenance during

72. See recent litigation by a group of milk producers association to block the government milk board's recent order regulating the supply of milk. Crowd of School Milk Producers Protest at Minister of Agriculture, NAEWNA (Mar. 31, 2018), http://www.naewna.com/politic/330418 (part $\mathrm{V}$ of this article examines the role of NGO attorneys who, unlike their corporate counterparts, are administrative court litigation trail blazers, a role acknowledged by Bangkok's global law firms); see also Marquer, supra note 50 .

73. See, e.g, Cross Cultural FOUNDATION, https://voicefromthais.wordpress.com (discussing a decision upholding administrative court jurisdiction over legal wrongs committed by government officers acting under color of martial law); Online Reporters, Thaksin's Passport Petition Rejected, KRUnGTHeP Business News (May 1, 2018, 1:20 PM), https://www.bangkokpost.com/news/politics/1455990/thaksins-passport-petition-rejected (rejecting Thaksin's appeal to have his passport restored but granting the appeal of a Thaksin aide). 
rehabilitation of the Creek. The Karen rejected a modest judgment in their favor in 2006 and appealed to the Supreme Court of Justice. In 2016, the Supreme Court affirmed and increased the damages award to 36 million baht or about $\$ 8,000$ for each of the plaintiffs.

A second case brought in administrative court in 2004 was based on an innovative argument advanced by NGO lawyers who argued that broad statutory language and seldom used regulations not only gave the PCD authority but also created a duty to order the polluter to undertake rehabilitation. Four years later, after multiple pleadings and other delays, the administrative court held that the PCD had failed to investigate the Karen claims. The administrative court also held that the PCD had a responsibility to remedy the pollution by ordering the company to rehabilitate Klity Creek. The PCD was ordered to pay for costs of its delay. The company appealed, delaying final decision by the Supreme Administrative Court until 2013 when final judgment was entered. The final decree ordered the PCD to develop a company rehabilitation plan and to pay each of the thirteen plaintiffs \$5, 402.

In 2018, twenty years after Klity Creek was first brought to the PCD's attention, the agency has not completed its remediation plan.

\section{Judicial "Support Structures"}

Part IV identified an unlikely class of litigants who lacked experience and possessed few resources: namely rural and urban community members who lost land, water, air quality, and sometimes their livelihood as a result of environmental damage primarily from business and infrastructure development projects in which the government collaborated or had enabled through licensing, franchising, or regulatory oversight. For those injured by such projects, administrative courts promised a remedy for collective grievances unavailable through political representation. As previously described, administrative court procedures were simplified to make low-cost litigation possible without a lawyer. A petition initiating a case required only a simple statement of facts, and court personnel assumed the burdens of investigating, documenting facts, and applying law. In practice, these informal procedures exacerbated disadvantages of wealth, education, and experience in resolving conflicts for litigants like these. An administrative court judge must decide whether a complaint is valid before proceeding. Both law and facts are important at this stage, especially when a controversy raises unfamiliar questions of law or requires subtle characterization of facts to persuade a judge to accept the matter for decision. Judges have often required multiple responsive filings, a process that, in a case like the Klity Creek litigation, could 
require years and might even be delayed by the judge to increase pressure for settlement. Further, the cost of multiple trips to a distant courthouse could well be prohibitive for a poor family. When the trial judge's investigation is complete, a panel of judges must examine the evidence and decide the merits of the claim, but not before comparing its conclusions with those of a single judge appointed by a separate process who also prepares a decision. At each point in this potentially lengthy process a litigant's participation might influence the outcome with the help of an experienced and skilled advocate.

Law training in Thailand, as in many civil law jurisdictions, emphasizes remaining within the letter of the statutory law rather than seeking "justice behind the law," in the words of one environmental advocate. Precise interpretation of statutory requirements can strengthen the rule of law and reinforce the legal obligations of those who might otherwise ignore them. Thus, some provisions of Thailand's 1992 Enhancement and Conservation of National Environmental Quality Act ${ }^{74}$ and the ministry regulations that have been routinely ignored might be enforced by a judiciary trained in strict statutory interpretation. But some key constitutional and statutory concepts are new to Thailand, and they require innovative interpretations. Provisions of the 1997 and 2007 Constitutions, which created rights to be informed and to participate in government decisions affecting the environment of a community, provide principles but not precise instructions to ministries. Flexible standards governing ministry discretion under administrative law are new to judges not accustomed to creating policy from broad principles. Even favorably inclined judges are on a steep learning curve. ${ }^{75}$ Court staff, burdened by large numbers of cases and the demands of investigation and development of each one, lack time and training to fill these gaps. ${ }^{76}$ Subtleties of substantive law are beyond the understanding of citizens who, lacking an attorney, would have to bring them forward on their own.

In general, Thailand lacks support for rights advocacy. ${ }^{77} \mathrm{~A}$ culture of

74. See Enhancement and Conservation of National Environmental Quality Act, B.E. 2535 (1992) (Thai), trans. available at http://portal.mrcmekong.org/assets/documents/ThaiLaw/Enhancement-and-Conservation-of-National-Environmental-Quality-Act-(1992).pdf.

75. E.g., id. at $\$ 35$ ("It shall be the duty of all government agencies concerned to take actions within their powers and functions that are necessary for effective implementation of the Environmental Quality Management Plan ....") Ministries have claimed that neither the Act nor ministry regulation provide a precise requirement for action, an "omission" the courts have been forced to consider in course of environmental litigation.

76. See Bishop, supra note 47 , at $30-35$.

77. Political scientist Charles Epp's comparative study of rights advocacy emphasizes the importance of "support structures" such as an independent, "organizationally adept," politically savvy, and adversarial legal profession, private funders and legal aid 
rights may be growing but remains weak. The Constitutional Court failed to develop the constitution's extensive bill of rights. ${ }^{78}$ Other than members of a self-sustaining network of social cause lawyers that formed after the October 1973 uprising, the legal profession provides little support to lawyers who take up social causes. ${ }^{79}$ Other comparative studies show that movements for rights may take hold when strong international pressure make rulers receptive to human rights. 80 International movements for human and environmental rights have had influence in Thailand, but their role has been limited by the absence of a stronger domestic advocacy. ${ }^{81}$

Notwithstanding litigation barriers and the absence of strong domestic advocacy for rights in general, Thailand has developed a system of support for environmental litigation, which resulted in remarkable administrative court decisions against government officials and entire ministries.

\section{The First Environmental Liligator}

An international environmental movement has grown steadily to address concerns about spillovers from development affecting valuable resources to the international community. ${ }^{82}$ When the first international

organizations, and rights consciousness among members of the public and constitutional court judges. See Epp, supra note 16. (Epp's list is notable for its Anglo-American centrism and the absence of similar institutional features in many developing legal systems).

78. See James R. Klein, The Battle for the Rule of Law in Thailand: The Constitutional Court of Thailand, in THe Constitutional Court OF Thailand: THE Provisions and THE Working OF THE COURT (Amara Raksasataya \& James R. Klein eds., 2003) (discussion of the early years of the Constitutional Court).

79. See Munger, supra note 1. (unlike the legal profession in the Anglo-American tradition, lawyers as profession in Thailand are fragmented and weak, and its elite members avoid politics and confrontations with the government. Advocacy for rights is not supported by a strong criminal defense bar, legal services organizations or domestic foundations).

80. See, e.g., Yves Dezalay \& Bryant G. Garth, Constructing Law Out of Power: Investing in Human Rights as an Alternative Political Strategy, in CAUSE LAWYERING AND THE State in A Global ERA (Austin Sarat \& Stuart Scheingold eds., 2001); Margaret Keck \& Kathryn Sikkink, ACTIVISTS Beyond Borders: Transnational AdvocaCy NETWORKS IN INTERNATIONAL POLITICS (1997).

81. See Frank W. Munger, Globalization, Investing in Law and the Careers of Lawyers for Social Causes: Taking on Rights in Thailand, 53 N.Y. L. SCH. L. REV. 745 (2008-2009).

82. The global commons include shared resources: air quality, water supply, pollution from pesticides and mining, deforestation, marine eco-system mismanagement, and general degradation of environmental quality. In actuality, local environmental conflicts often concern the unequal impact of development on historically disadvantaged communities, which exacerbates political and social inequalities and raises questions about governance. For example, the Pak Mun Dam in northeastern Thailand-an infamous 
advocates for environmental rights appeared, Thailand's NGO community was already deeply involved in supporting community resistance to burdens imposed on them by development, but not by means of litigation. ${ }^{83}$

As the popular movement for constitutional reform peaked in the late 1990s, Surachai Throngam, the son of a soldier and a curry rice street vendor, joined three other activist lawyers to form the first private law firm in Thailand dedicated to social causes. Administrative courts changed everything for these lawyers by giving them new strategies, new careers, and, unexpectedly, a new professional identity. Surachai filed his first administrative court case shortly after the courts opened in 2001. By persuading the judges to interpret their power broadly, he won an unprecedented judgment ordering Thailand's atomic energy agency to use its discretionary authority to protect the public from negligent disposal of radioactive waste by issuing more effective standards. His case tested the administrative courts' willingness, in his words, to "push the law" by interpreting general constitutional and statutory principles ignored in practice by ministries responsible for preventing such threats to the public. In a parallel civil court case against the private waste disposal company, he won damages for the community, a remedy seldom sought by individuals because of the litigation expenses and the low price of settlement. Tandem victories in the two court systems were important because of the connection between government ministries and private industry. His success has not been lost on attorneys in private practice, who can earn a fee financed by a damage award, as well as other social cause attorneys. ${ }^{84}$

World Bank funded dam project in Thailand--is one among many large-scale water management projects that displaced entire villages, destroyed local culture, and damaged ecosystems that sustained local populations. See Chris Sneddon \& Coleen Fox, Struggles Over Dams as Struggles for Justice: The World Commission on Dams (WCD) and AntiDam Campaigns in Thailand and Mozambique, 21 SOC'Y \& NAT. RES. 625 (2006).

83. The language used by local leaders might include claims for "rights," rights they believed protected by the new Constitution, but they were defined in concrete termsprotecting a customary way of life, sustaining local ecology, their strong desire for equality, and, especially after 1997, recognition that government had responsibilities to them. Interviews were conducted by the authors with numerous organizers between 2006 2014. See Prudhisan Jumbala \& Maneerat Mitprasat, Non-Governmental Development Organisations: Empowerment and Environment, in POLITICAL CHANGE IN THAILAND: DEMOCRACY AND PARTICIPATION (Kevin Hewison ed., 1997); Philip Hirsch. The Politics of Environment: Opposition and Legitimacy, in POLITICAL CHANGE IN THAILAND: DEMOCRACY AND PARTICIPATION (Kevin Hewison ed., 1997).

84. Only a few have pursued the harder and less remunerative path of innovative administrative court litigation, and until 2015, when the civil procedure code was amended to permit class actions, the effort required to litigate on behalf of large numbers of individual plaintiffs continued to limit their interest. 
In 2001, an American foundation seeking corporate philanthropic opportunities to fund anti-pollution litigation sought suggestions for a recipient in Thailand. Although Surachai's inability to speak any foreign language was considered a limitation by his colleagues, he was chosen by peers to lead this project because of his unique litigation experience and his many connections with NGOs, academics, and human rights lawyers. As Director of EnLAW, ${ }^{85}$ Surachai became what was perhaps Thailand's first lawyer to "play for rules" 86 in the administrative courts, which set an example for attorneys beyond his circle of disciples among younger generations of social cause lawyers. In turn, the administrative courts have been receptive to this approach, by relying on prior court decisions under similar circumstances or accepting administrative law decisions from a foreign court, such as the U.S. Supreme Court, as persuasive authority for innovative interpretations of Thai law. 87

In the post-constitutional movement, the small community of lawyers for social causes formed working groups to follow this strategy for carefully selected cases. Surachai quickly became the litigation expert for the environmental working group. His leadership of the Klity Creek litigation working group and involvement in other well-publicized environmental cases brought his expertise to the public's attention. 88 Human Rights Watch lauded the Klity Creek decision as the first to order a ministry to enforce the law by requiring a private company to clean up pollution. ${ }^{89}$ For Surachai, the Klity Creek litigation had

85. See ENLAWTHAI FOUNDATION, http://enlawfoundation.org/newweb/?page_id=1643 (2008). EnLaw has published two volumes of narratives about its cases. See ENLAWTHAI Found, ENVIRONMENTAL JUSTICE: ESSAYS AND INTERVIEWS ABOUT ENVIRONMENTAL LAWSUITS (2008).

86. "Playing for rules" is a term widely used in sociolegal research to refer to litigation that attempts to establish rules or policy that will apply in future cases. See Marc Galanter, Why the 'Haves' Come Out Ahead: Speculations on the Limits of Legal Change, 9 L. \& SOC'Y REV. 165 (1974).

87. In Thailand's civil law jurisprudence, similar to France's, court decisions are not considered precedent, but decisions are considered persuasive authority. Methods for circulating decisions among lawyers in practice are slowly developing. Because these systems are undeveloped, publicity for Surachai's litigation has been important, as is networking and training among social cause lawyers.

88. Interview with the Director of the Water Quality Department of Pollution Control Division, Mr. Boonchob Suthaanuswon (July 7, 2007); see also Simachaya, supra note 48.

89. See Thailand: Clean Up Klity Creek: Confront Toxic Legacy Before Reopening Lead Mines, HuMAN RIGHTS WATCH (Dec 15, 2014, 6:45 PM), https://www.hrw.org/news/2014/12/15/thailand-clean-klity-creek (the Klity Creek decision created a remedy for environmental damages by implying an affirmative duty to take preventive action from the broad language of the Environmental Quality Act and Section 57 of the constitution and to establish a "polluter pays" standard). 
additional lessons. 90 The opportunity to pursue a judicial remedy would have been meaningless without compensation for costs the attorneys could not control, including, in the Klity Creek case, maintenance for families that had lost a means of livelihood and travel costs incurred during protracted proceedings. The court was persuaded to provide a remedy for the families' cost of living, but not travel, and required the villagers to pay small but burdensome court fees. ${ }^{91}$

Increasing publicity and praise for environmental litigation in the administrative courts has changed Surachai's professional identity. Success as a litigator has led to him to invest more of his effort in litigation and far less in direct contact with the communities whose NGO representatives initially selected him to become their advocate. Initially an effective organizer who spoke directly to potential litigants in the field, he has sacrificed much of that role to become the consummate professional litigator, an expert in environmental and administrative law, an important contact among litigators abroad, and a valuable consultant for government officials in Thailand. ${ }^{92}$ Surachai has trained a group of dedicated younger lawyers, and their success has encouraged others outside his law firm to bring environmental law suits. ${ }^{93}$ As a result, environmental litigation in the administrative courts has become a self-sustaining and expanding area of entrepreneurial law practice.

For courts and lawyers, conditions have changed rapidly since 1997. The constitution that created the administrative court system and the Constitutional Court have been modified twice after military interventions in 2006 and 2014. New constitutions modified the selection process for the Constitutional Court but otherwise left both the

90. According to Richard Pearshouse, senior researcher at Human Rights Watch, Klity Creek was a success in part because the Karen village maintained itself as a cohesive social group committed to a common end. For this he credits their shared ethnic identity and the presence of NGO workers who helped sustain the group's morale. See id.

91. The administrative courts have since amended their practice to permit waiver of fees, and in some cases, they have awarded travel expenses. Interviews with one of Surachai's proteges, an experienced administrative court public interest litigator Sor. Rattanamanee Pokla (Dec. 8, 2014, and Apr. 3, 2017).

92. Interviews with EnLAW Director Surachai Trongam (June 16, 2007; Feb. 27, 2008; June 29, 2008; June 30, 2009; Dec. 10, 2014) (Surachai's lack of foreign language skills remains a major obstacle, but he employs younger attorneys fluent in English who serve a link to experts in other countries).

93. Surachai's litigation is particularly effective because of his two-pronged strategy of seeking compensation in the civil courts and policy change in the administrative courts. Other lawyers, however, have been more selective, some drawn to the financial rewards of bringing damage claims against the private partners of government development projects and others seeking the publicity attained by victories in litigation against the government itself. 
Constitutional Court and the administrative court system intact. During interim periods under military rule, the organic law and statutory authority of the administrative courts remained in force. After restoration of an elected government in 2007, disruptive street protests continued to interfere with normal life in Bangkok and sometimes shut down key government institutions. Elite and middle-class dissatisfaction mounted with Red Shirt populists who continued to dominate elections. In 2014, following an election disrupted by opponents of the Red Shirt government, Prime Minister Yingluck Shinawatra was accused of abuse of power ${ }^{94}$ and removed from office by the Constitutional Court. Shortly after, the military overthrew her successor. The military junta in power since 2014 has broken an unspoken rule that required returning power to a civilian government within a relatively short time. Instead, the junta has remained in power and exercised control over both policy development and the country's political life.

Prospects for robust electoral democracy are considerably weaker as the military deploys arrest and "reeducation" for those considered politically disruptive and applies Thailand's lese majeste laws, a relic from the age of monarchs that is used by military friends to suppress a broad range of expression deemed a challenge to the authority of the country's present rulers. ${ }^{95}$ In 2016, the junta conducted a carefully controlled popular referendum to approve adoption of a constitution designed to perpetuate the military's influence over Thailand's political future.

Surachai's likely affinity with the Red Shirt movement might be articulated privately among friends, but in public he is the consummate litigator with a valued skill. His growing professional identity invokes norms of political neutrality that the military government has respected. Ironically, the military's limitations on the public space for political dissent has been matched by reliance on formal legality to maintain its legitimacy, a strategy that preserves the appearance of a rule of law by allowing courts, often military, to adjudicate cases of those it has arrested under laws adopted by the military's appointed

94. See Case Closed on Thawil Pleinsri's Case: Opening of Administrative Court's Personnel Administration Division, supra note 61.

95. Restrictive laws govern public meetings and use of the Internet. The stated purpose of these limitations on speech and assembly is to control politically partisan expression and campaigning rather than public meetings or use of the internet in general. Civil courts have upheld most of these charges, occasionally finding arrests procedurally defective, but often applying lese majeste laws in instances where the interests of the monarchy have been difficult for observers to discern. See DAVID STRECKFUSS, TRUTH ON Trial: Defamation, Treason, and Lese-Majeste (Rethinking Southeast ASIA) (2011) (it is also true that many non-political public protests are conducted without interference). 
Legislative Assembly or by junta regulations permitted under the 2016 Constitution. Notwithstanding harassment and arrests of attorneys representing opponents of the military government or those that monitor and disseminate information about the government's violations of human and constitutional rights, ${ }^{96}$ attorneys are pursuing robust non-political litigation against government ministries, their private partners, and development projects. Judicial independence supported by international recognition of judicial decisions that uphold non-political rights seems to have created some protection for attorneys who defend non-political rights.

\section{Assessing the Support Structure for Administrative Courts}

The differences and similarities between the outcomes of Kadar Toy and Klity Creek litigation are a place to begin assessing the strength of the support system for litigation in the administrative courts. The Klity Creek decisions, other than the international praise they drew, yielded no more concrete benefits for litigants than the Kadar Toy settlement. The civil damages awarded to each litigant in the cases were very similar. The pressure that the Klity Creek litigation in the administrative courts placed on the Pollution Control Department to create policy providing far greater protection to the public in the future is of great long-term significance. ${ }^{97}$ Yet, few of the rights won in cases like Klity Creek have had immediate benefits or resulted in immediate policy change. Thai ministries are inefficient and subject to outside influence, and change is complicated by multiple overlapping responsibilities among ministries that encourages buck-passing. Of course, projects that have been blocked by the courts remain blocked, in some cases preserving villages or vital ecosystems from destruction. These results confer immediate and far reaching benefits.

The limited capacity of courts to make lasting policy changes is not a dilemma unique to Thailand, 98 and, as our analysis has suggested, courts have other important functions through deployment of their

96. See Thailand: Events of 2017, HUMAN RIGHTS WATCH,

https:/www.hrw.org/world-report/2018/country-chapters/thailand (last visited on July 24, 2018).

97. One of Surachai's collaborators says she regularly pressures administrative court judges to expand the scope of policy interpretation to encompass risk elimination. Interview with Sor.Rattanamanee Pokla (2014).

98. See generally Gerald N. Rosenburg, The Hallow Hope; Can Courts Bring ABOUT SOCIAL CHANGE (1991) (comparing how the ineffectiveness of U.S. litigation campaigns is due to "backlash" of organized counter-measures by the targets of litigation, Thailand suffers from overall absence of effective enforcement mechanisms and outright resistance from agencies). 
concurrent, convening, and expressive powers. ${ }^{99}$ First, the power to review actions undertaken by officials enables administrative courts to break up and re-center bureaucratic and political control of policies created within Thailand's insular and tradition-bound ministries or within its limited political space (concurrent power). Further, administrative court proceedings potentially require officials to respond to other stakeholders, which creates opportunities to negotiate outcomes serving a wider range of interests (convening power). Finally, through litigation, citizens denied more direct political access to government or a forum in which to express their views may "have their day in court" and an opportunity to appeal for wider support (expressive power). In turn, an interested public 100 or an attentive media seeking interviews with the parties and further news coverage ${ }^{101}$ may greatly increase the responsiveness of officials. 102

Thus, litigation has benefits not measurable by court orders. Other functions of courts-political and expressive-are consequential. Litigation removes the timing, and content of public discussion of ministry responsibilities is removed from ministry and political control. Cases have drawn publicity, and publicity has placed ministry decisions in the middle of an ongoing public discourse about rights. Ministries must acknowledge the oversight role of courts and explain to a court, and sometimes to the public at large, why they have acted as they do. Thus, litigation may be one means by which the 1997 Constitution's principle that citizens have rights (and a right to have rights) can become a firm expectation.

Institutional factors suggest that systemic change through

99. See Dowdle, supra note 14.

100. Bishop provides evidence of the expressive function of courts in the Map Ta Phut litigation, which has increased popular awareness and willingness to mobilize for more general political action. See Bishop, supra note 47, at 113-17.

101. Administrative cases and decision are frequently reported by the press and ministry decisions and the administrative courts themselves have been the subject of commentary and interviews. See Vijarn Simachaya, Deputy Director General of Pollution Control Department Opens Up about "Map Ta Phut"... Underground Water Contamination - Volatile Organic Compound Causes Cancer, ThaiPublica [in Thai] (Mar. 2, 2012), http://thaipublica.org/2012/03/wijarn-simachaya-maptaput-pollution/.

102. See, e.g., The PCD's rapid, but ultimately ineffective response to Klity Creek pollution followed NGO release of the Klity Creek story. Similarly, ministries and politicians responded quickly to the international publicity given the Map Ta Phut decisions. Bishop, supra note 47, at 93.

Information about important litigation appears not only on the administrative courts' website but on the Pollution Control Department's web pages. See Pollution Control DEP'T,http://www.ped.go.th/Info_serv/pol_maptapoot_airnd.cfm?yy=2018;

http//www.ped.go.th/Download/pollution_kity.cfm; and Pollution Control Department, FACEBOOK, https://www.facebook.com/PCD.go.th. 
litigation will be limited. The successes of environmental rights litigation in the administrative courts has not been replicated, for example, for labor rights or work place safety litigation. ${ }^{103}$ The absence of successful litigation that contest ministerial failure to fulfill public mandates is in part due to Thai substantive law and the control of litigation by specialized labor courts, ${ }^{104}$ but it is also a reflection of another contingency - the necessity of mobilized group support. ${ }^{105}$ Rural communities are overrepresented among litigants in environmental cases because they are natural solidary groups, sometimes with indigenous leadership or long-standing NGO support that has long been recognized as a legitimate voice for popular concerns. Further, in societies with a longer history of litigation for rights, backlash has limited gains from playing for rules. 106 Bangkok's "global" law firms recognize the importance of environmental regulation and are prepared. ${ }^{107}$ Therefore, in the long run gains through litigation may depend to an increasing degree on litigation's other functionsstrengthening rights consciousness and expectations for compliance with law, building social movements, and creating pressure for more far-reaching policy change.

In place of a strong constitutional court, administrative court judges are changing the force of law simply by adhering to its terms and occasionally by adopting broad and innovative interpretations of environmental rights. In the absence of a strong rights-oriented legal profession, a small self-sustaining community of lawyers for social causes brings cases challenging government policies to the courts.

103. One exception may be litigation by consumers in both civil and administrative courts, which seems to be increasingly popular. The Foundation for Consumers raised public awareness with well-publicized administrative court litigation to block a government plan to privatize Thailand's electrical power supplier. Attorneys learned quickly that some consumer cases reaped publicity and financial rewards. See Frank Munger, Revolution Imagined: Cause Advocacy, Consumer Rights, and the Evolving Role of NGOs in Thailand, 9 ASIAN J. COMP. L. 29, 44-51 (2015).

104. For example, the Labor Court, which resolves most employee matters is appealable to the civil courts. Little effective litigation seems to have been brought on behalf of employees in these courts or in the administrative courts.

105. Labor mobilization has long been suppressed by the Thai government, providing a partial explanation for weak support for similar administrative court litigation. See, e.g., Sakdina Chatrakul Na Ayudhya, The Thai Labour Movement: Strength Through Unity: Challenges and Recommendations, FRIEDERICH EBERT STIFTUNG (Oct. 2010), http:/library.fes.de/pdf-files/bueros/thailand/07563.pdf.

106. See ROSENBURG, supra note 98.

107. For example, Baker McKenzie, and other "global" corporate law firms, regularly update web postings on environmental law. See, e.g., Amendment to Environmental Act in Thailand: Penalties Imposed on Development without EIA, BAKER MCKENZIE (May 3, 2018), https://www.bakermckenzie.com/en/insight/publications/2018/05/amendment-toenvironmental-act. 
Because the work of this community lacks domestic financial support, seed money has often been found abroad, which has helped found or sustain marginal law practices defending rights. As these ties have become stronger after litigation successes, not only environmental rights but also courts and the work of lawyers defending rights have increasing legitimacy. Reciprocally, courts have continued to enforce and develop environmental rights, which has encouraged a few more cases. The numbers of cases remain small, and the increasing credibility of the administrative courts and the lawyers who litigate their cases may be the most important outcome.

\section{CONCLUSION}

Part $V$ of this article examined the mutual construction of administrative court authority, advocate careers, and communities supporting the long process of administrative court litigation. The political and constitutional legacy of the administrative courts is one of the keys to understanding their subsequent development as institutions embedded in routines of litigation. Notwithstanding the continuing influence of Thailand's monarchy-centered civic religion, traditions of deference, and patron-client relationships, Thailand's judiciary has rendered decisions showing that it embraces a norm of independence. ${ }^{108}$

This article emphasized other factors that are likely to be important in developing countries, namely the development of support structures within and outside the court system. Unlike the Thai Constitutional Court, the administrative courts have created a network of advocates and communities willing to litigate to protect existing statutory and constitutional rights and to create new ones. Foreign seed money has allowed some litigators to sustain litigation that provides little compensation for the advocate. Like aid that for years has attempted to encourage responsible civil society advocacy, support for litigation has planted seeds of self-sustaining careers, and in turn, encouraged more litigation both by the beneficiaries of aid and others who learned from their example. In turn, international and domestic public support for

108. Independence is not the same apolitical, but rather it is the ability to keep political ideology confined within legal norms and values, enabling a judge to reach decisions that limit the power of bureaucrats and politicians. Upham, supra note 45 , at 88-90. Thailand's judiciary has a reputation for being relatively free from corruption compared with some other Southeast Asian courts. See, e.g., Chattham Prasongchanya, A Comparison of the Appointment of the Judges in Thailand and Australia in terms of Judicial Independence, OFF. INT'L AFF., OFF. JUDICIARY (2013) http://www.oia.coj.go.th/doc/data/oia/oia 1500436241.pdf (last visited Jul. 22, 2018) (comparing the appointment of judges in Thailand and Australia). 
decisions curbing the powers of government officials and politicians has undoubtedly reinforced the professional identity of judges themselves. The administrative courts' growing legitimacy as an institution has had repercussions for those who have become experts in litigation by creating a legitimate and respected career path that has shielded them from political reprisals under the present military government.

The greatest obstacle to independent review of executive authority in Thailand has not been the lack of an independent judiciary but the dominant bureaucratic structure of the Thai state. Thai ministries, especially those supported by international business and financial interests, have sufficient political power to manipulate policymaking to undermine adverse administrative court decisions by means of strategies that preempt administrative court authority. ${ }^{109}$ Some scholars suggest measuring the functions of the new Thai courts, as well as those of other developing countries, by their "consequential" political role in regime survival or transformation. ${ }^{110}$ As this article has explained, opportunities for the administrative courts to play such a determinative role in the fate of a political regime in Thailand are limited. Measured instead by the outcome of confrontations over the power exercised routinely by those acting for the state in lesser roles, the administrative courts have demonstrated capacity for independence.

The question remains: have Thailand's administrative courts had an impact on Thai society and, more particularly, have they become an alternative path to the rule of law? Viewing the administrative courts and their supporting social system through a longer lens, since the 1970 s, demographic and economic changes have given rise to demands for new rights, many of which found means of expression in Thailand's institutional and political space. In response, change has grown from multiple points and at many different levels, sometimes with foreign seed money. In turn, small changes, sometimes brought about by litigation, have increased the efficacy of social movements, their leaders, and to some degree their participants, as the Klity Creek and Map Ta Phut litigations illustrate. Most of all, administrative courts have routinized claims-making against the government. While investing in litigation instead of direct political action is a much-debated strategy for political change in Thailand, successful litigation in the administrative courts by the environmental movement seems to have opened a door for new rights. As sociolegal scholar Lauren Edelman observes, law should be considered at least in part as endogenous and constructed in and

109. For a detailed analysis of this case, see Bishop, supra note 47 .

110. See Tom Ginsburg, The Politics of Courts in Democratization Four Junctures in Asia, in Consequential Courts: Judiclal Roles in Global Perspective 45 (Diana Kapiszewski, et al. eds., 2013). 
through the organizational fields that it seeks to regulate. ${ }^{111}$ The mutual construction of an independent judiciary and law-abiding officials is a prime example of endogenous legal change. The administrative court judiciary, with its mandate to secure constitutional and statutory accountability of private and government actors, is showing signs of establishing an effective support system for incremental realization of these expectations and becoming a force for the progressive growth of a rule of law.

111. Lauren B. Edelman, Legality and the Endogeneity of Law, in LEGALITY AND Community: One the Intellectual LeGaCy of Philip SELZnick 187, 192-93 (Robert A. Kagan et al. eds., 2002). 
